\title{
Japanese Geographers and Their Studies on the Third World after the Second World War: A Critical Review
}

\author{
Keichi KumagaI \\ Department of Geography, Ochanomizu University, Bunkyo, Tokyo 112-8610, Japan
}

\begin{abstract}
This paper critically reviews Japanese geographers' contribution to Third World research in the postwar period. The author highlights the discrepancies between the geographers studying the Third World and geographical circles within Japan. In the pioneering period (pre mid-1960s) some active Japanese geographers independently commenced their work on the Third World without much institutional support. They established their own style of research mainly depending on participatory observation methods. In the following period (mid-1960s to 1970s), some large scale research projects were organized by major geographical departments in Japan. The University of Tsukuba's research project on Northeastern Brazil and Hiroshima University's research project on rural India are the two major ones. These research projects consisted of both physical and human geographers and adopted more extensive research methods. Since the 1980 s, much more interdisciplinary research has been organized and an increasing number of younger geographers entered Third World studies. However, there has not yet been much interaction between these geographers studying the Third World and other mainstream geographers in order to innovate research methodology and epistemology of the discipline. It should be the crucial task for contemporary geographical research in Japan.
\end{abstract}

Key words: Third World studies, regional geography, area studies, fieldwork, geographical circles in Japan

\section{Introduction}

Japanese geographers have made distinguished contributions to Third World research since the end of the Second World War. ${ }^{1}$ While the number of the geographers studying the Third World has been growing, their works and results have been on the margins of Japanese academic geography. This paper aims to consider the reason by reviewing their work and pinpoint specific problems. In particular, it highlights divergences between the work of those studying the Third World and conventional geographical circles within Japan. It is a kind of contextual approach to situate Japanese geographers' research and practices concerning the Third World within the institutional structure and academic circles of geography in postwar Japan.

This paper has been difficult to write as the theme is too broad. Reviewing and evaluating the enormous volume of research on the Third
World undertaken by Japanese geographers is beyond an individual author's capability. ${ }^{2}$ No one could ever imagine to review all the studies undertaken by Japanese geographers on Western countries in the post-war Japan. Additionally, any study inevitably reflects the author's bias towards particular topics and regions. ${ }^{3}$

The definition of 'the Third World' is itself problematical. The term has been popular in Japan since the 1970s. Originally it had some political connotations, but it is now used in association with 'less developed' or 'developing' countries. Its usage has become less precise, because of the emergence of the NIEs as well as the virtual demise of the socialist Second World.

In this paper, 'the Third World' is almost equivalent to the 'non-Western world' besides Japan. Research on mainland China and Korea, however, is generally omitted, mostly because of the very large number of articles by Japanese academics on these areas. It deserves another 
paper.

\section{Journal Articles on the Third World}

General trends in the development of Japanese geographical research on the Third World are derived from a survey of the number of the articles which have appeared in Japan's leading academic journals. Three journals are selected. They are published by the major national geographical societies; 'Geographical Review of Japan' (Chirigaku Hyoron) by the Association of Japanese Geographers; 'The Human Geography' (Jinbun-Chiri) by the Human Geographical Society of Japan; and 'Annals of the Japan Association of Economic Geographers' (KeizaiChirigaku Nenpo) by the Japan Association of Economic Geographers. Geographical Review of Japan has been issued monthly since its establishment except 1944, and the Human Geography bimonthly. Annals of the Japan Association of Economic Geographers had been issued annually until 1965, from when it was published quarterly.

\section{Geographical Review of Japan}

Geographical Review of Japan (the Review) was first published in 1924. The Review is older than the other two which were founded since the Second World War. The Review publishes articles on both physical and human geography, whereas the other two only publish on the latter. The Review is of particular interest because it permits a comparison of pre- and post-war trends in Japanese geographical studies.

All articles carried in the Review have been divided into the following two categories: (a) physical geography; and (b) human and regional geography. Regional geography often contains both physical and human geographical perspectives. Only articles belonging to the second category were classified according to their geographical areas or regions. ${ }^{4}(1)$ Japan; (2) East Asia (Korea, China, Mongolia etc. including prewar Japanese colonies); (3) Southeast Asia; (4) South Asia; (5) West Asia or Middle East; (6) Africa; (7) Latin America; (8) Pacific Islands (excluding New Zealand); (9) Australia and New Zealand; (10) West Europe;
(11) USSR and East Europe; (12) North America; and (13) non-regional articles (on theory, methodology, geographical history and multiregional articles). Categories from (2) to (8) concern 'the Third World'. The results are shown in Table 1.

The total number of articles on human and regional geography are almost equivalent to the number of articles on physical geography. The following trends are observed.

1) Most articles have been areal or regional case studies rather than theoretical or methodological studies.

2) Among the regions, Japan occupied a dominant position, especially after the Second World War. Its share has been constantly around 90 per cent. This suggest postwar Japanese geographers have been 'inward-looking'.

3) The above trends were not marked during the first decade of the Review (1925-34), when more varied research topics and regions were studied. Ironically, Japanese geographers were most 'internationalized' during this initial period of Japanese academic geography.

4) Other than Japan, East Asia has been the most popular region which includes pre-war colonies such as Korea, Taiwan and Manchuria before and during the war. ${ }^{5}$ This was followed by Europe. Other Asian regions as well as Africa, Latin America and the Pacific Islands have been rarely selected for study. This trend has persisted until the 1990s. ${ }^{6}$

These observations highlight that 'the Third World' has not been an important topic for the Review, except for the short period before and during the Pacific War when Japan had its colonies and intended to invade the surrounding areas. This does not necessarily mean that many Japanese geographers made direct or positive contributions to the execution of the War (Nippon Chiri-Gakkai 1975), although there were a few geographers committed to the war effort in various ways. There have been few papers on the Third World in the Review even since the 1970s, when the Japanese economy began to have a more intensive relationship with, and a greater impact upon, the Third World. 
Table 1. Articles in the Geographical Review of Japan classified by the regions of their subject

\begin{tabular}{|c|c|c|c|c|c|c|c|}
\hline Regions as subject & $1925-34$ & $1935-44$ & $1947-59$ & $1960-69$ & $1970-79$ & $1980-89$ & $1990-95$ \\
\hline ( 1 ) Japan & 103 & 159 & 287 & 159 & 173 & 108 & 85 \\
\hline ( 2 ) East Asia & $8^{a}$ & $10^{\mathrm{a}}$ & 6 & 5 & 6 & 5 & 2 \\
\hline ( 3 ) Southeast Asia & 0 & 2 & 2 & 3 & 0 & 1 & 0 \\
\hline (4) South Asia & 0 & 0 & 1 & 0 & 0 & 1 & 0 \\
\hline ( 5 ) West Asia/Middle East & 0 & 0 & 0 & 0 & 0 & 1 & 0 \\
\hline ( 6 ) Africa & 1 & 0 & 0 & 0 & 0 & 0 & 1 \\
\hline ( 7 ) Latin America & 0 & 0 & 1 & 0 & 3 & 0 & 1 \\
\hline ( 8 ) Pacific Islands & $3^{\mathrm{b}}$ & 0 & 0 & 0 & 0 & 0 & 0 \\
\hline (9) Australia \& New Zealand & 2 & 0 & 0 & 0 & 0 & 0 & 1 \\
\hline (10) West Europe & 7 & 2 & 2 & 7 & 8 & 2 & 2 \\
\hline (11) USSR and East Europe & $4^{c}$ & 0 & 0 & 1 & 3 & 0 & 0 \\
\hline (12) North America & 2 & 1 & 1 & 4 & 1 & 4 & 1 \\
\hline $\begin{array}{l}\text { Articles with particular regions as } \\
\text { subject (a) }\end{array}$ & 130 & 174 & 300 & 179 & 194 & 122 & 93 \\
\hline (13) No particular region as subject & 49 & 10 & 18 & 11 & 40 & 21 & 16 \\
\hline $\begin{array}{l}\text { Articles in human \& regional } \\
\text { geography }\end{array}$ & 179 & 184 & 318 & 190 & 234 & 143 & 109 \\
\hline Articles in physical geography (b) & 225 & 140 & 189 & 183 & 232 & 249 & 105 \\
\hline Total number of articles in GRJ & 404 & 324 & 507 & 373 & 466 & 392 & 214 \\
\hline Share of Japan as subject (1)/(a) [\%] & 79.2 & 91.4 & 95.7 & 88.8 & 89.2 & 88.5 & 91.4 \\
\hline $\begin{array}{l}\text { Share of the Third World as subject } \\
\qquad(2-8) /(a)[\%]\end{array}$ & 9.2 & 6.9 & 3.3 & 4.5 & 4.6 & 6.6 & 4.3 \\
\hline
\end{tabular}

a including prewar colony of Japan (Korea, Taiwan, Northeastern China).

b including 'the Nanyo' archipelagos (Micronesia) under Japanese rule.

c including Karafuto (Sakhalin).

\section{The Human Geography and Annals of the Japan Association of Economic Geographers}

The same procedure was adopted in examining trends in two other main Japanese geographical journals: 'The Human Geography' and 'Annals of the Japan Association of Economic Geographers'.

The Human Geography was first published in 1948. Table 2 lists the geographical regions by the journal's articles. The following characteristics should be pointed out here;

1) In Human Geography, the ratio of papers on Japan to papers on other areas was over 80 per cent, but did not reach the preponderance exhibited in the Review.

2) The proportion of papers on Third World topics has been constantly higher than the Review.

3) Among Third World regions, East Asia was the most important region covered. This trend was evident during the 1950s and 1960s, when overseas fieldwork was most difficult for Japanese geographers. Consequently, they were mainly historical and cultural studies depending on secondary sources. ${ }^{7}$

4) Since 1990 there has been a significant increase in the number of Third World studies, especially on Asian countries.

Annals of the Japan Association of Economic Geographers (the Annals) was first published in 1954. Table 3 shows the distribution of regions in the Annals. As this journal had a smaller number of articles before 1970, the absolute number of the articles on the Third World has been low and even declined during 1970s. Since then, the number of papers on the Third World has increased markedly. Over one fifth of the articles between 1990 and 1995 were on the Third World. ${ }^{8}$ 
Table 2. Articles in the Human Geography classified by the regions of their subject

\begin{tabular}{|c|c|c|c|c|c|}
\hline Regions as subject & $1948-59$ & $1960-69$ & $1970-79$ & $1980-89$ & $1990-95$ \\
\hline ( 1 ) Japan & 220 & 200 & 192 & 189 & 100 \\
\hline ( 2 ) East Asia & 11 & 12 & 5 & 9 & 10 \\
\hline ( 3 ) Southeast Asia & 2 & 3 & 0 & 0 & 4 \\
\hline (4) South Asia & 0 & 3 & 2 & 3 & 3 \\
\hline ( 5 ) West Asia/Middle East & 2 & 3 & 0 & 2 & 0 \\
\hline (6) Africa & 2 & 2 & 1 & 3 & 1 \\
\hline ( 7 ) Latin America & 4 & 0 & 6 & 2 & 0 \\
\hline ( 8 ) Pacific Islands & 0 & 1 & 1 & 0 & 0 \\
\hline (9) Australia \& New Zealand & 2 & 0 & 0 & 1 & 1 \\
\hline (10) West Europe & 9 & 15 & 6 & 7 & 5 \\
\hline (11) USSR and East Europe & 5 & 9 & 4 & 3 & 0 \\
\hline (12) North America & 10 & 1 & 4 & 10 & 5 \\
\hline Articles with particular regions as subject (a) & 267 & 249 & 221 & 229 & 129 \\
\hline (13) No particular region as subject & 54 & 54 & 25 & 34 & 28 \\
\hline Total number of articles in the Human Geography & 321 & 303 & 246 & 263 & 157 \\
\hline Share of Japan as subject $(1) /(a)[\%]$ & 82.4 & 80.3 & 86.9 & 82.5 & 77.5 \\
\hline Sharesof the Third World as subject $(2-8) /(a)[\%]$ & 7.9 & 9.6 & 6.8 & 8.3 & 14.0 \\
\hline
\end{tabular}

Table 3. Articles in Annals of the Association of Japan Economic Geographers classified by the regions of their subject

\begin{tabular}{|c|c|c|c|c|c|}
\hline Regions as subject & $1954-60$ & $1961-69$ & $1970-79$ & $1980-89$ & 1990-95 \\
\hline ( 1 ) Japan & 16 & 38 & 73 & 117 & 48 \\
\hline ( 2 ) East Asia & 0 & 1 & 2 & 6 & 7 \\
\hline ( 3 ) Southeast Asia & 0 & 0 & 1 & 1 & 6 \\
\hline (4) South Asia & 1 & 0 & 1 & 1 & 1 \\
\hline ( 5 ) West Asia/Middle East & $0.5^{\mathrm{a}}$ & 1 & 0 & 2 & 0 \\
\hline (6) Africa & 0 & 0 & 0 & 0 & 0 \\
\hline ( 7 ) Latin America & $1.5^{\mathrm{a}}$ & 3 & 1 & 2 & 1 \\
\hline ( 8 ) Pacific Islands & 0 & 0 & 0 & 1 & 0 \\
\hline ( 9 ) Australia \& New Zealand & 0 & 0 & 0 & 0 & 1 \\
\hline (10) West Europe & 0 & 3 & 6 & 6 & 2 \\
\hline (11) USSR and East Europe & 2 & 0 & 0 & 1 & 3 \\
\hline (12) North America & 2 & 1 & 1 & 1 & 2 \\
\hline Articles with particular regions as subject (a) & 23 & 47 & 85 & 138 & 71 \\
\hline (13) No particular region as subject & 15 & 8 & 26 & 33 & 21 \\
\hline Total number of articles in A. A. J.E.G & 38 & 55 & 111 & 171 & 92 \\
\hline Share of Japan as subject $(1) /(a)[\%]$ & 69.6 & 80.9 & 85.9 & 84.5 & 67.6 \\
\hline Share of the Third World as subject $(2-8) /(a)[\%]$ & 13.0 & 10.6 & 5.9 & 9.4 & 21.1 \\
\hline
\end{tabular}

a An article discussing trends in regional developments of both Turkey and Central America is counted as 0.5 each.

\section{Trends in journal articles on the Third World}

The following trends are found in journal articles of geography in general in postwar Japan. First, they have concentrated overwhelmingly on empirical case studies of Japan.
Secondly, the number of articles on the Third World was very low until the 1970s. Thirdly, there has been a steady increase in articles on the Third World since the 1980s in both Human Geography and the Annals. Clearly, increasing numbers of overseas students from Korea and 
China who are studying their own countries have contributed to this trend (Chai 1991; Han 1982, 1988, 1993; Jeon 1982, 1983; Joo 1982; Kim Doo-Chui 1995; Kim Song-Mee 1991; Nam 1981a, 1981b; Park 1995; Xu Pei-Wei and Saito 1994; Xu Wei-Dong 1987, 1989, 1990, 1992; Xu Wei-Dong, Shirasaka and Ichikawa 1990; Youn 1987). ${ }^{9}$

The number of articles appearing in these journals, however, is not necessarily a sound guide to research undertaken by Japanese academic geographers. Authors of articles in these journals are mostly from the 20 s to 40 s age group (postgraduate students or junior academic staff). Refereed papers are of value to them in acquiring positions in universities or other institutions as well as to improve their academic careers. In Japan, postgraduate students have little chance to conduct overseas research for themselves. ${ }^{10}$ They thus tend to publish their academic papers on empirical case studies within Japan. On the other hand, senior academic staff have a variety of opportunities for publication other than academic journals, such as the annals published by their own departments, faculties or universities, as well as writing their own books. Therefore they write more un-refereed papers than graduate students or junior academic staff. Finally, most overseas research is derived from Overseas Scientific Research Grants by Japan's Ministry of Education, Science and Culture, and the results are often published first as reports for the Ministry. Only a few of them are later contributed to academic journals.

\section{Third World Research before the Mid-1960s}

Research on the Third World after the second World War is reviewed and critically evaluated by examining the work during three postwar periods: 1) pre mid-1960s; 2) mid-1960s to $1970 \mathrm{~s}$; and 3 ) since the $1980 \mathrm{~s}$.

\section{'Pioneering' Japanese geographers on Third World studies}

The 'pioneering period' for Japanese geographical research in the Third World stretched from the end of the Second World War to the mid-1960s. As Japan lost its prewar colonies and the economy was depressed, there was no stimulation to study overseas during the first half of this period.

Academic Japanese geographers preferred domestic study because they had little chance of conducting overseas research by themselves. The active commitment of a few Japanese geographers to the war effort might be another deterrent. Some geographers were involved as Shiseikan (advisers for military governance in the area under Japanese occupation) or participated in field research sponsored by Japanese military forces. Others contributed ideological articles advocating Chiseigaku (geopolitics) (see Takeuchi 1974).

A few younger geographers, however, were willing to start their research on the Third World despite these difficulties. There were only two possible ways for them to do their own field research in the Third World countries: one was to visit the particular country by themselves with funds mostly from overseas institutions; and the other was to participate as a member of a scientific expedition organized sporadically by universities or academic societies, which was sponsored by private companies or/and the government.

These opportunities were rare, but a number of geographers successfully and enthusiastically commenced their careers in studies on the Third World during this period. They are listed in Table 4. These 'pioneering' geographers led studies on the Third World in postwar Japan.

Jiro Kawakita first carried out research on Nepal in 1953 as a member of the Japanese scientific expedition of the Nepal-Himalayan area (Kawakita 1957). Subsequently, he revisited Nepal many times until the mid-1970s. His approach was mainly a cultural-ecological one (see Kobayashi, S. 1991; Takayama and Kobayashi 1991). He paid attention to the interrelationship between temperature, vegetation, and human subsistence activities to clarify the distinctive vertical structure of the NepalHimalayan cultural complex (Kawakita 1974, 1977). Kawakita (1973) has also a keen interest in methodology of field studies as well as publishing a number of popular essays for general readers (Kawakita 1987). 
Table 4. The 'pioneering' Japanese geographers for studies on the Third World in postwar Japan

\begin{tabular}{|c|c|c|c|}
\hline Name & Year of Birth & $\begin{array}{l}\text { Main field } \\
\text { research area }\end{array}$ & University or Institute mainly belonged \\
\hline Kawakita, J. & $1920 \sim$ & Nepal & $\begin{array}{l}\text { Osaka City Univ. } \\
\text { Univ. of Tsukuba }\end{array}$ \\
\hline Iwata, $\mathrm{K}$. & $1922 \sim$ & Laos, Thailand & $\begin{array}{l}\text { Osaka City Univ. } \\
\text { National Museum of Ethnology }\end{array}$ \\
\hline Kamozawa, I. & $1924 \sim$ & Turkey & Hosei Univ. \\
\hline Kobori, I. & $1924 \sim$ & Southwest Asia & Univ. of Tokyo \\
\hline Ohno, M. & $1925 \sim$ & Iran & Inst. of Oriental Culture (Univ. of Tokyo) \\
\hline Ishikawa, E. & $1925 \sim$ & Pacific Islands & $\begin{array}{l}\text { Rikkyo Univ. } \\
\text { Tokyo Metropolitan Univ. (Dept. of Social Anthropology) }\end{array}$ \\
\hline Sueo, Y. & $1927 \sim$ & Southwest Asia & $\begin{array}{l}\text { Kyoto Univ. } \\
\text { Kansai Univ. }\end{array}$ \\
\hline Nishikawa, D. & $1928 \sim$ & Brazil & Hosei Univ. \\
\hline Koga, M. & $1930 \sim$ & India & $\begin{array}{l}\text { Inst. of Oriental Culture } \\
\text { Inst. for Economic Research (Osaka City Univ.) } \\
\text { Hitotsubashi Univ. }\end{array}$ \\
\hline Takahashi, A. & $1932 \sim$ & Philippines & $\begin{array}{l}\text { Inst. of Developing Economies } \\
\text { Univ. of Tokyo (Faculty of Economics) }\end{array}$ \\
\hline Tomosugi, T. & $1932 \sim$ & Thailand & $\begin{array}{l}\text { Inst. of Developing Economies } \\
\text { Rikkyo Univ. } \\
\text { Inst. of Oriental Culture }\end{array}$ \\
\hline Ohiwakawa, K. & $1933 \sim 81$ & Israel & $\begin{array}{l}\text { Inst. of Developing Economies } \\
\text { Meiji Univ. }\end{array}$ \\
\hline
\end{tabular}

Keiji Iwata commenced his overseas field study in $1957-58$ as a member of the research expedition on cultures of rice-cultivating peoples in Southeast Asia organized by the Japanese Association of Ethnology. During the latter part of this expedition, he conducted his own intensive field research on one particular village in northern Laos using participant observation methods (Iwata 1958, 1971b). He has continued his research on rural society in northern Thailand (Iwata 1963, 1964) and ethnic minorities in Southeast Asia (Iwata 1971 a). In later years he has devoted his research to contemplating the cosmology of animistic belief (Iwata 1973).

Iwao Kamozawa is well-known rather as a distinguished economic geographer in Japan than a researcher on the Third World. However, while Kamozawa devoted his energy to establish a theory for regional economic geography, he started to study Turkey by himself in the late 1950s. (Kamozawa 1958, 1967, 1969). Kamozawa (1988) has been studying regional economy and regional policy in Turkey as well as being concerned with the ethnic minority question.

Iwao Kobori (1959) first visited Iran, Iraq and Syria in 1956, as a member of the archaeological research team led by Namio Egami of Tokyo University who had been a leading archaeologist in Japan. Since then Kobori has continued his research on the irrigation system in Southwest Asia.

Yoshiyuki Sueo first visited Iran, Afghanistan and Pakistan in 1959, with Takeo Oda, his senior colleague from the Department of Geography of the University of Kyoto, with a grant from Japan's Ministry of Education, Science and Culture (Oda 1960; Sueo 1961). He has continued his research on water supply in Southwest Asia, especially. Turkey (Sueo 1985, 1989).

Morio Ohno began his fieldwork by studying fishery villages in Japan. He visited Brazil in 1956 as a member of the research team on the upper Manaus for the purpose of searching suitable settlement area for Japanese immigrants. It was sponsored by International Immigration Study Group of Japan's Ministry of Foreign Affairs. Ohno (1965-67) shifted his own field- 
work to Iranian villages and published a lot of inspiring monographs contemplating the methodology of fieldwork (Ohno 1969, 1971, 1974, 1977).

Daijiro Nishikawa had once engaged in research on Japanese fishery villages in cooperation with Ohno. He visited Paraguay in 1963 to undertake research on the immigrant villages of Japanese settlers, which was funded by the International Immigration Study Group (Nishikawa 1965). Since then he has continued his studies on South America, especially Brazil, focusing on the regional structure of agriculture system (Nishikawa 1968, 1974a, 1974b) as well as performing intensive surveys of the life histories of Japanese immigrants (Nishikawa 1990). Nishikawa (1985) has also been deeply concerning about the methodology of regional geography.

Akira Takahashi, instead of participating in these expeditions, first studied at the University of Philippines from 1958 to 1960, with a grant from the Philippine government. While studying at the University, he commenced his own field surveys in rural villages. Since then Takahashi (1967, 1969a, 1969b, 1977, 1982a) has been engaged in intensive research on the socio-economic characteristics of Central Luzon villages.

Iwao Ohiwakawa initiated his fieldwork on Israel as a student at the Hebrew University of Jerusalem. He concentrated his research on kibbutzim (Ohiwakawa 1964, 1969). Ohiwakawa (1983) was Japan's most distinguished researcher on contemporary Israel until his early death in 1981.

\section{The pioneering geographers and the institu- tional structure of Japanese geography}

The following characteristics should be highlighted on the relationships between these pioneering geographers' research on the Third World and the institutional structure of Japanese geography.

First, there were two major geography departments that produced these researchers: the Department of Geography at the University of Kyoto and the Department of Geography at the University of Tokyo. Among researchers listed in Table 1, Kawakita, Iwata, Ishikawa and Sueo were graduates from Kyoto University, and Kamozawa, Kobori, Ohno, Nishikawa, Koga, Takahashi, Tomosugi and Ohiwakawa were graduates from the University of Tokyo.

There were some differences in approach between these two groups. Researchers from the University of Tokyo concentrated on socioeconomic questions, whereas those from the University of Kyoto were more interested in cultural aspects. Indeed, Kawakita, Iwata, and Ishikawa subsequently changed their main discipline from human geography to cultural anthropology or worked on the border of the two disciplines. ${ }^{11}$

Secondly, most of these researchers had worked in specific departments of geography or research institutions: the Department of Geography in Osaka City University, Department of Geography at Rikkyo University, the Institute of Oriental Culture in University of Tokyo, and the Institute of Developing Economies.

The Department of Geography at Osaka City University, where Kawakita and Iwata had once worked together, was founded in 1949. Yoshihiko Yabuuchi who specialized in fishery culture in the Pacific later joined as one of the academic staff. Under Shigeki Muramatsu's initiative, the Department conducted intensive field survey in different parts of Japan. This must have stimulated Kawakita and Iwata to conduct overseas fieldwork (see Kawakita 1973).

The Department of Geography at Rikkyo University was also founded in 1949. This Department was headed by Atsuhiko Bekki. He graduated from Kyoto University and worked as an adviser for the military governance in Indonesia during the War. As he has specialized in cultural geography of Southeast Asia and the surrounding areas (Bekki 1951, 1957, 1959, 1960a, 1960b, 1969, 1977), researchers with similar interests were recruited, such as Eikichi Ishikawa and Takashi Tomosugi. Ishikawa soon changed his discipline to ethnology and moved to the Department of Social Anthropology at Tokyo Metropolitan University. He was one of the pioneering Japanese academics engaged in studying the Pacific Islands (Ishikawa 1992) and later founded the Japanese Society for Oceanic Studies. 
Tomosugi did his research on Thailand as well as other Southeast and South Asian countries. His methodology was embedded not only in human geography but economic history and economic anthropology (Tomosugi 1969, 1980, 1983, 1989, 1990, 1991).

The Institute of Oriental Culture (Toyo Bunka Kenkyujo) was originally established in 1941. Koji Iizuka, well known by his translation work of P. Vidal de la Blache's classical text, was the most renowned human geographer in the Institute, in both the prewar and postwar period (Iizuka 1950). He published many articles and essays not only for academics but also for general readers. He made a field trip in Manchuria and Mongolia in 1945, though this interesting essay had not been published until his death (Iizuka 1972). Although Iizuka himself was not a 'real' field worker, he was so stimulating that he inspired Ohno, Nishikawa, Koga, Takahashi, Tomosugi and Ohiwakawa to undertake overseas research, especially on Asian countries.

The Institute of Developing Economies (Ajia Keizai Kenkyujo) was founded in 1960, under the supervision of Japan's Ministry of International Trade and Industry. The institute comprises a large number of researchers specializing on various parts of the Third World. The institute not only sent staff to the countries of their specialty but also organized many study groups which involved researchers from outside. The institute has become the prime Japanese centre for area studies. The Institute has employed not a few geographers and provided others with opportunities to publish their research work in its monthly journal (Ajia Keizai) and the occasional research monographs (e.g. Takahashi 1969a; Tomosugi 1980; Taniuchi 1982).

Finally, the research undertaken by these pioneering geographers was superior to most contemporary works in other disciplines not only in quantity but also in quality. These pioneering researchers, however, were not situated in the mainstream of Japanese academic geography.

Most of the departments and research institutions to which these researchers belonged were ones newly established after the War and thus only occupied a marginal position in Japanese geographical circles at that time. These geographers therefore were less involved in educating students majoring in geography. Instead, these researchers managed to undertake their own overseas research independently using the participant observation method which was not popular among other Japanese geographers. In these circumstances, these pioneering geographers were becoming critical of the conventionality of contemporary Japanese geography and geographers, and often identified their work more with area studies or other disciplines such as cultural anthropology than with human geography.

Unfortunately, these pioneering geographers' studies on the Third World did not have much influence upon contemporary Japanese academic geography. Consequently, not many geographers specializing on the Third World appeared during the next decade. Their critical and reflective methodologies based upon intensive overseas fieldwork (e.g. Iwata 1971b, Kawakita 1973, Ohno 1969, 1974, 1977) was not held in high esteem by their colleagues in Japanese geography.

\section{Third World Research from Mid-1960s to $1970 \mathrm{~s}$}

Changed circumstances for overseas research emerged in the mid-1960s. The major change was the 'institutionalization' of Japanese academics' overseas research. It was mainly brought about by the introduction of Overseas Scientific Research Grants by Japan's Ministry of Education, Science and Culture since 1963. Thereafter several major geography departments in Japan commenced their own research projects on the Third World. ${ }^{12}$

Two research projects were remarkable because of their scale and results: the Northeastern Brazil project of the Department of Geography at Tokyo University of Education (University of Tsukuba) since 1966, and the rural India project of the Department of Geography at Hiroshima University since 1967.

\section{The Northeastern Brazil research project of the University of Tsukuba}

The Department of Geography in the Tokyo 
University of Education commenced their first research expedition to Northeast Brazil in 1966-67. This was headed by Eiichiro Fukui, a leading climatologist in Japan. Between 1971 and $1972-73$, this research continued under the title of 'Scientific Research on Natural Environment of Northeast Brazil'. As the title suggests the research focused on physical geography rather than human geography. The main members of the research, Masami Ichikawa, Tadashi Machida, Soki Yamamoto, Toshie Nishizawa, Eiji Matsumoto and Noboru Hida were all physical geographers, with the exception of Shozo Yamamoto and Mario Hiraoka. ${ }^{13}$

The research continued after the Tokyo University of Education was restructured and renamed the University of Tsukuba in 1973. The second stage, which commenced in 197980 , was headed by Masami Ichikawa who specialized on hydrology. The three main topics in this research agenda were again mainly topics in physical geography: 1) characteristics of natural ecosystems in a tropical semi-arid region; 2) present-day agricultural land use and their problems, and 3) endemic diseases and their relationship to tropical ecosystems (Ichikawa 1981). ${ }^{14}$ Later two more human geographers, Isao Saito and Noritaka Yagasaki, took part in the project and contributed to adding human geographical aspects to the research agenda (Saito and Yagasaki 1987, 1990, 1991; Saito, Yagasaki, Pazela and Mullar 1986; Yagasaki and Saito 1992), although the emphasis on physical geography persisted. ${ }^{15}$

An enormous amount of data has been collected in this long-running research project. A number of papers in English and in Japanese have published. Most of those written in English were issued either in the 'Science Report of Geoscience' of the University of Tsukuba or in 'Latin American Studies', the journal published by the Special Project on Latin America since 1980 (later reorganized into Centro de Estudos Latinoamericanos). The latter journal was published as the research expanded beyond the Department into more comprehensive and interdisciplinary Latin American studies project at the University of Tsukuba.

\section{The rural India research project of Hiroshima University}

The Department of Geography in Hiroshima University commenced its overseas research project in 1967-68, under the title of the Changes in Indian Villages'. The project continued in 1969-70 and 1972-73. In 1978 the field was moved from North India to South India in 1978, and further work was undertaken in 1980-81 and 1982. Its research on rural India has continued for almost thirty years and is still in progress. The results have been issued in a number of research monographs written in English (Ishida 1974; Fujiwara 1980, 1982, 1984) and in Japanese (Yonekura 1973; Ishida 1975; Fujiwara, Murakami, Nakayama and Maida 1987), as well as in many academic papers (Fujiwara and Nakayama 1985; Fujiwara and Sadataka 1988; Nakayama 1972; Nakayama, Fujiwara and Kitagawa 1979).

This long-term project was conceived by Jiro Yonekura who had been in Southeast Asia, mainly Indochina, during the Second World War. The research was carefully planned with the long-term perspective in mind. Before commencing research, under Yonekura's guidance, the other four members of the research team were sent to study abroad to acquire language ability and research skills. They were Yoshimi Komoguchi, Makoto Murakami, Shuichi Nakayama and Takashi Nakada. They studied in Dacca University, Singapore University, Banaras Hindu University and Calcutta University, respectively (Fujiwara, Murakami, Nakayama and Maida 1987).

The first stage of the research from 1967 to 1973 was conducted under the leadership of Yonekura. Later Hiroshi Ishida, a cultural geographer, took the leadership. He had undertaken field research on livestock farming in New Zealand (see Nakayama 1991). The second stage of the research from 1978 to 1982 was led by Kenzo Fujiwara, geomorphologist with experience in Japanese scientific expeditions to Antarctica. The main research topics were the introduction of regional development, with an emphasis on the "green revolution", and its impact on spatial systems of the "rural areas of 
South India', as well as to determine 'whether the people acclimatize well or not to their natural environment in South India' (Fujiwara 1980: 3). The research was conducted in selected sample villages with different natural environments and socio-economic situations (Fujiwara $1980,1982,1984)$. In the second stage, more human geographers were added to the project. They were Kenji Kitagawa, Toshiaki Ohji (Univ. of Kyoto), Iwao Maida, and Tsuguo Nakasato (Fukuoka Univ. of Education) who later published many of their own papers on India (Kitagawa 1987; Maida et al. 1992). Among them, Ohji's and Nakasato's works are remarkable. Ohji (1964, 1977, 1984, 1986, 1987, $1993,1995)$ has elaborated his insight on agricultural techniques in the Indian sub-continent, while Nakasato $(1964,1977,1987)$ has tackled the issue of bovine keeping in both India and Japan in terms of social perspective.

\section{The projects organized by the geographical departments and their results}

The research projects conducted by the geographers of the Tsukuba and the Hiroshima Departments had several characteristics in common. First, their research was long-term; secondly, both physical geographers and human geographers were involved; thirdly, much detailed information was gathered on a wide range of topics such as natural environment, land use or socio-economic conditions; fourthly, the research was conducted extensively rather than through participant observation because a number of villages or research sites were visited in a short period of time; and finally, much use was made of microscale mapping techniques which were not popular in other disciplines for studying the Third World.

These characteristics suggest their style of research had many advantages over the sporadic and individualistic efforts of the pioneering geographers. There were, however, also some problems or limitations with this new approach.

While the above research succeeded in collecting a large quantity of data, the qualitative data dependent upon the researchers' value judgments was neglected. Much of this re- search led to a deeper understanding of the natural environment and land use at the local scale through detailed data collecting and mapping. It paid, however, less attention to local or regional socio-political structures. The results of their research was not presented in a way to stimulate Third World studies in other disciplines within Japan. In other words, there was little interaction between these geographers and other academics studying the same area. $^{16}$

The lack of interaction was partly due to the research involving both physical and human geographers. The physical scientists tend to believe that all useful data must be objective and value-free. As the research was often conducted under the initiative of physical geographers, such attitudes might affect human geographers in their topic selection. Additionally, human geographers at that time also favoured a positivistic approach imbued with techniques generated during geography's 'quantitative revolution'.

It was unfortunate that the circulation of the research results was confined to Japanese geographical circles and a few counterpart geographers in the host countries. Geographical points of view and techniques concerning manenvironment relations should have had more impact on Third World studies in other disciplines.

\section{A research project on the Torres Strait Islands}

Besides these two large scale projects, there were research expeditions conducted by other geographers. Research on Torres Strait Islands, on the border between Australia and Papua New Guinea, was commenced in 1975 under the leadership of Yoshihiko Yabuuchi. Yabuuchi had studied fishing cultures in the Pacific (Yabuuchi 1963, 1967, 1969). After Yabuuchi's sudden death, George Ohshima took over leadership, and undertook research both in 1977 and 1979. Ohshima has also studied fishery and cultural geography of maritime people (Ohshima 1986, 1988). He conducted a fieldwork on Palawan Island as a leader of Kwansei-gakuin University's research expedition in 1967 and 1968. Later he extended his 
interests in the Pacific, to Taiwan, Philippines, Borneo and Papua New Guinea (see Tawa 1991).

The uniqueness of the research on Torres Strait Islands was its focus on cultural aspects using participant observation (Ohshima 1983). Hisatsugu Sugimoto, Seiji Hashimoto, Hiroyuki Matsumoto who joined the research, were all graduated from the Department of Geography at Osaka City University. They have studied cultural geography under Yabuuchi, Kawakita and Iwata's influence. Sugimoto (1972) himself had undertaken research on Western Samoa in $1965,1974,1980$, before taking part in this new research. Then he published his own papers on the Torres Strait villages (Sugimoto 1978, 1982). Hashimoto $(1979,1990)$ continued his research interest in Melanesia. Matsumoto (1980, 1991) using anthropological methods provided fascinating monographs on the Torres Strait Islanders' culture.

\section{Recent Trends in Third World Studies since 1980s}

Since the end of the 1970s, Japan's improved economy and appreciation of the yen led to an increase in overseas travel by the Japanese. This changed situation also increased the opportunities for academics to undertake overseas research even if they had to use their own funds.

In the meantime, Japanese research institutes have organized and supported a number of overseas research projects and study groups on the Third World. The major organizations have been the Institute of Developing Economies founded in 1960, the Center for Southeast Asian Studies at Kyoto University, which publishes 'the Southeast Asian Studies', founded in 1963, the Institute for the Study of Languages and Cultures of Asia and Africa at Tokyo University of Foreign Studies founded in 1964, and the National Museum of Ethnology founded in 1974. They stimulated interdisciplinary research and contributed to the development of area studies in Japan focused on the Third World.

This development led to the blooming of Japanese research on the Third World. The following three points are remarkable. First, a number of inter- or multi-disciplinary field research and study groups including many geographers were organized on various aspects of the Third World topics. They are mostly supported by either research institutes or the Japanese Government. Secondly, a number of books on particular countries or regions in the Third World were written by individuals or groups of geographers. Thirdly, an increasing number of younger geographers born in the 1950s and the 1960s have entered Third World studies.

\section{Organized research and study groups}

New features appeared in the research conducted by Japanese human geographers. There has been an increase of interdisciplinary research including academics in other disciplines. In long-running research projects such as Hiroshima University's program, a larger number of human geographers took part focusing on the social and economic dimensions (Murakami et al. 1993, 1995; Nakasato et al. 1992; Okahashi et al. 1992; Tomozawa et al. 1992). Consequently, conventional geographical methods of man-environment relationships have been augmented by a variety of interests in historical, socio-economic and political aspects. ${ }^{17}$

Hiroshi Ishihara, Department of Geography in Nagoya University at that time, organized research on 'Traditional Markets and Traders in Indian Subcontinent' and undertook fieldwork in Bangladesh, India and Nepal, between 1985 and 1987. Although a study on periodic market systems was a popular topic in human geography (Ishihara 1969, 1973, 1980; Ohji 1986; Mizuno 1987), little field research has been undertaken in the Third World by Japanese academics. Ishihara's research $(1987,1988$, 1989) was a rare exception. The research involved two economists, one anthropologist and one historian as well as two human geographers: Tunetoshi Mizoguchi and Yoshihiro Miyamachi. This diversity of membership was a great advantage in studying 'markets', essentially an interdisciplinary subject. Mizoguchi and Miyamachi also published their own papers in academic journals (Mizoguchi 1987; Miyamachi 1989). 
Yoshiyuki Sueo has continued his interest in water utilization in Southwest Asia or arid Asia. He organized the field research in 1985, under the title of 'Geographical Survey about Origin, Dispersal and Fixation of the Water Utilization Techniques in Arid Asia' (Sueo 1985, 1989). Together with four human geographers -Akinobu Terasaka, Kiyonori Kanasaka, Akitoshi Hiraoka and Shigeru Nakajima-two agricultural economists joined their research team. While Sueo paid much attention to traditional water use techniques, two agricultural economists focused on contemporary topics such as the relationship between development of irrigation and rural socio-economic change. Kanasaka (1985a, 1985b) also published his own papers on water supply.

Terasaka organized another research group and conducted fieldwork in Turkey in 1987, 1989, 1990, 1991 and 1992. Their earlier research focused on the historical urban development and regional structure of Turkish cities (Terasaka 1989, 1992). Among the seven authors contributing to the book on changing urban structure of Ankara published in Japanese (Terasaka 1994), two were historians. Three active geographers - Itsuki Nakabayashi, Toshio Mizuuchi and Yoshiki Wakabayashiexamined Ankara's urban problems using general models and techniques derived from contemporary behavioural geography. Although their approach was still on trial and might neglect the particular regional or local context, the research is appreciated as it showed the possible interrelationship between the new geographical approaches and field research on the Third World.

Mizuuchi (1985) also published a paper on spatial formation of a Japanese colonial city which is a crucial topic remaining to be tackled by Japanese geographers. Seii Yoh's (1989, 1994) research on Taipei is a fine exception.

Masanori Koga, after moving to the Department of Geography in Hitotsubashi University in 1982, organized two study groups on Third World cities in 1983-84 and 1985-86 respectively. Both of them were supported by grants from Japan's Ministry of Education, Science and Culture. Koga, one of the pioneering geographers studying on the Third World, has had a long experience in research on India since the late 1950s. He has published a number of papers with socio-economic aspects on various topics such as regional development and national policy, the impacts of 'green revolution', rural-urban migration, or overseas migrants from India (Koga 1958, 1964, 1970, 1980, 1981, 1987). His close association with specialists on India is reflected in both study groups comprising a historian, sociologist, economist, demographer and anthropologist. The first study group was organized under the title of "A Comparative Study of the Metropolitan Cities in the Third World' and the results were published in English (Koga 1985). Apart from Koga, two other human geographers contributed to the issue: the late Isamu Ota on Singapore; and Kanasaka on Turkey.

The second study group focused on comparative studies of urban segregation, one of the popular topics in social geography. Six geographers including Koga contributed to the final report (Koga 1987). Two studies were on ethnic minorities in cities in developed countries: Kenji Yamamoto on Turkish migrants in München; and Tatsuya Chiba on Koreans in Japanese cities. Three case studies on Third World cities were also presented: Koga on Bombay; Masanori Naito on Damascus; and Shuhei Shimada on Nigerian cities. These papers, together with Keichi Kumagai's review paper on urban segregation in the Third World, highlighted the need to reconsider the concept of segregation in the Third World context where it had been imposed by the colonial power.

The Institute of Developing Economies (IDE) has supported a number of interdisciplinary study groups since its establishment. The results of these studies were published by the Institute. Many geographers contributed to these publishments either as an editor or a writer. Among the series of books published by IDE, Nishikawa edited a book on agricultural systems in Latin America (Nishikawa 1974b), Hiromitsu Umehara edited three books on comparative studies on changing agricultural systems and rural communities in Southeast Asia (Umehara 1988, 1991; Umehara and Mizuno 1993), and Kumagai edited a book on socio- 
political changes in Pacific Island nations (Kumagai and Shiota 1994). Mikio Hirato (1976) who has studied Malaysia contributed several papers to the book on political and socio-economic change in Malaysia (Hirato 1988).

Hiroshi Kawabe, a specialist in both demography and geography, organized a study group on urban system in developing countries supported by IDE. Among five contributors to the book published by IDE (Kawabe 1988), four were geographers. They were: Kawabe (Introduction, the Philippines); Masanori Naito (Syria); Hisako Kurihara (Mexico); and Tetsuo Sato (Bangladesh). Kurihara $(1974,1978)$ once undertook fieldwork on Mexico City and reconsidered the concept of marginality of Latin American cities. Although the urban system or urban hierarchy was another popular topic in human geography, it has been discussed only within a Western context (Fujimaki 1984). Kawabe highlighted that urban primacy in developing countries should not be considered within national urban hierarchies but as a part of the global urban system.

\section{Published books on the Third World written by geographers}

A number of geographical texts on Third World issues have been published since the 1980 s. $^{18}$ A few books written by senior geographers during the 1960s and the 1970s were mostly conventional regional geographies (e.g. Bekki 1960b, 1969, 1977; Kikuchi 1966; Yamaguchi 1970). The geographers' books appearing since the 1980s range from published $\mathrm{PhD}$ theses (Nakayama 1982; Yamashita 1988; Umehara 1992; Shimada 1992; Hashimoto 1992; Tanabe 1994) to innovative regional geographies (Tomosugi 1990; Ishizuka 1991). Collectively they reflect the growing maturity of Japanese geographical studies on Third World topics.

Most of these books have been written on Asian countries: Umehara (1992) on Philippines; Yamashita (1988) and Ota (1994) on Singapore; Nakayama (1982) and Komoguchi (1986) on India; Tomosugi (1990) on Sri Lanka; and Tanabe (1994) on Thailand. Also there are some books on other regions: Shimada (1992) on Nigeria; Taniuchi on Papua New Guinea (1982); Hashimoto (1992) on Melanesia; and Ishizuka (1991) on the Caribbean Islands.

Umehara started his studies on the Philippines since the early 1960s when he worked at the Institute of Developing Economies. He has conducted intensive fieldwork in villages in both the central Luzon and the Panai Islands. Umehara (1970-71, 1978, 1988, 1991, 1993) published many papers and edited some books in the Institute. In his comprehensive study on rural villages in the Philippines, Umehara (1992) analysed changes in rice-cultivating villages by examining interrelationships between land systems, cultivation techniques and the socioeconomic stratification in rural communities. Relying on his own field observations, Umehara $(1978,1987)$ demonstrated the so-called 'green revolution' has provided more benefits to the 'commercial elite' than rural peasants.

Kiyomi Yamashita commenced his research on Singapore as an overseas student at Nanyang University in 1978-80. His research focused on residential segregation patterns among Chinese dialect groups (Yamashita $1985,1986,1988)$. He observed the history of residential segregation was closely related to specialization in particular trading activities. Yamashita (1987) also provided general readers with a comparative study on China towns in Southeast Asia.

Isamu Ota who had once specialized in industrial geography began his research on Singapore in 1967. After a spell as a visiting professor at Nanyang University in 1975, he changed his main interests to socio-cultural geography. Subsequently, he has undertaken research on changing Chinese culture under Singapore's national integration policy (Ota 1976, 1985a, 1985b, 1994). Ota (1997) had also insisted on the need for social relevancy in Japanese human geography and criticized the conservatism of Japanese academic geographers until his untimely death in 1996.

Nakayama's research on India dates back to his involvement as a member of the Hiroshima University's Department of Geography project. He studied at Banaras Hindu University with a scholarship from the Indian government and 
received his first $\mathrm{PhD}$ there. Besides playing a role in the research project, Nakayama (1972) developed his own interests in industrialization and regional change in North India. Using field observation, he described industrialization at different regional scales: villages; rural market centers; regional towns; and industrial cities (Nakayama 1982). Nakayama (1986) also reviewed urban studies of Indian academics.

Yoshimi Komoguchi was also one of the founder members of Hiroshima University's project on India (Komoguchi 1972). Then he joined the South Indian Research Project organized by the Institute for the Study of Languages and Cultures of Asia and Africa, and undertook field research in both 1979-80 and 1981-82. His research monograph was published as a research paper from the Department of Geography at the University of Chicago. This monograph provided detailed micro-level village survey using precise mapping techniques (Komoguchi 1986). Komoguchi (198890) had continued to elaborate on his work on rural communities in Bangladesh as well as conducting field research in rural Malaysia until his untimely death in 1997 (Komoguchi 1995, 1996).

Tomosugi, as mentioned before, was one of the pioneering geographers of Third World studies in Japan. Tomosugi $(1969,1980,1983)$ has undertaken his research on Thailand using a variety of methods drawn from human geography, social and economic history and economic anthropology. His book written on Galle, south Sri Lanka, was an imaginative regional geography which demonstrated his interdisciprinary skills (Tomosugi 1990). He 'read' the urban landscape of Galle as a text with accumulated historical memories derived from trading activities. Tomosugi $(1989,1991,1993)$ also analysed Bangkok using the same methodology. He has also continued long-range field research on a village in central Thailand (Tomosugi 1995).

Shigeharu Tanabe identifies himself as a cultural anthropologist, although he graduated from the Department of Geography at the University of Kyoto. Tanabe $(1972,1976)$ has conducted field research in Thailand since the early 1970 s, recently shifting his focus on religion, ritual and ideology. His book, a modified version of his $\mathrm{PhD}$ thesis submitted to the School of Oriental and African Studies, University of London, reflects his earlier interest on the interrelationship between the lives of peasants and their environments (Tanabe 1994). His study provides a 'thick' description of farming systems and practical technologies in both Chiang Mai and Ayuttaya. His study not only incorporated ecological factors but also external forces affecting the development of peasant production.

Shuhei Shimada has been studying Nigeria since the mid-1970s when he too worked at the Institute of Developing Economies. After he moved to the Department of Geography in Tohoku University, Shimada has actively continued his research on Nigeria. This has covered a wide range of topics from colonial history to current socio-economic problems at local, regional, national and global levels (Shimada 1981, 1989). In his book, Shimada (1992) outlined how regional conflicts in Nigeria stemmed from the North being favoured by the colonial regime and analysed contemporary regional problems in relation to national policy. Pointing out the difference between regional conflicts and ethnic conflicts in Nigeria, Shimada claimed that the geographical perspective was valid for considering regional problems.

Toru Taniuchi, Department of Human Geography, University of Tokyo, also worked in the Institute of Developing Economies. While he is well known as an Australian specialist, he visited Papua New Guinea in 1973 and 1976. Although his subsequent book is compact, it provides a balanced regional geography of Papua New Guinea by focusing on socioeconomic characteristics instead of exotic traditional cultures (Taniuchi 1982).

Hashimoto has continued his field research in Melanesia after joining the research project on Torres Strait Islands. His book entitled 'Melanesia' consists of four studies of Fiji, Torres Islands, Southwest coast of Papua New Guinea and New Guinea Highlands (Hashimoto 1992). In particular, the description of cultivation system in Fiji was most detailed. His key concept was ' $b a$ ' (place or locality) in which 
human agencies with a common culture have been interacting with their environment.

Michiko Ishizuka has undertaken research on the Caribbean Islands since the mid-1970s. Her research covered a wide range of topics from fishermen's culture to feminist studies. The distinctive character of her research was reflected in the analysis of dynamic changes in spatial cognition of the Caribbean (Ishizuka 1985, 1987). Ishizuka noted the Martinique Islanders were now losing their 'traditional' plantation landscape which had been imposed by French colonisers. An ecological nationalist movement has emerged among the Martinique people to preserve their 'home' landscape (Ishizuka 1991). This case study shows the cultural dynamics of the Caribbean and the way in which the landscape has shaped their identity.

\section{Younger geographers on Third World studies}

Clearly, the new trend is that an increasing number of younger geographers born since the 1950s are willing to tackle Third World Studies. They have not come from particular 'schools', but commenced their wide ranging overseas research independently without much support from departments or research institutions.

In 1990, a book was written by the Kansai region's (the region around Osaka, Kyoto and Kobe) younger geographers' study group (Ajia Chiri Kenkyukai 1990). The book dealt with current issues in the NIEs and ASEAN. This book was epochmaking on several counts. This study group was spontaneously formed by members gathered from different universities without any organizer or sponsorship, which was a most unusual occurrence in Japanese geographical circles. The group was primarily interested in recent changes in Asian countries and in discovering new frameworks or methodologies to study them. Consequently, this book, used multidisciplinary methods: economics, sociology, anthropology as well as geography. The final product was a new type of regional geography for general readers. Twelve geographers contributed to this book: Shigeru Nakajima (industrialization and regional disparity in Korea), Chiwai Cheung (export processing zones mainly in Taiwan), Hiromasa
Kato (Japanese direct investment and technology transfer to Asian countries), Michio Akiyama (environment problems in Malaysia), Masaki Takayama (population policy in Singapore), Osamu Kitajima (urban transport in ASEAN), Masato Ikuta (commercial development in Kuala Lumpur), Keichi Kumagai (kampung and informal sector in Jakarta), Masami Fujimaki (squatter settlements in Kuala Lumpur), Shinpei Segawa (urban migrants and ethnicity in Jakarta), Shinichi Kosaki (agricultural development in Malaysia), and Haruo Noma (colonial geography and southeast Asia).

These geographers have continued their research work on Asia. Cheung has been undertaking research on mainland China, Hong Kong and Taiwan focusing on drastic economic change and urban growth in these areas. Ikuta $(1993,1994,1995)$ has studied Malaysian urban development in terms of formative international urban system in Southeast Asia. Fujimaki $(1989,1993)$ continued his interest on Malaysian squatter settlements as well as revising the viewpoints of Third World studies. Segawa (1995) has considered his work on the relationship between Jakarta's urban landscape and power of the state.

Noma $(1982,1988)$ reviewed time allocation studies in the Third World context and conducted field research on Thailand and Bangladesh. He is distinguished by his broad perspective and methodology, ranging from historico-geographical approach to the appraisal of rural development projects (Noma 1990, 1995a, 1995b).

The National Museum of Ethnology was founded on the initiative of Tadao Umesao, a most influential cultural anthropologist of the 'Kyoto School'. After Umesao's retirement, Komei Sasaki-a graduate of the Department of Geography at Kyoto University specialising in studies of shifting cultivation in both Japan and Southeast Asia (Sasaki 1957, 1970)-took the Presidency of the Museum. At the Museum there are not a few geographers or exgeographers, such as Motoko Katakura (1987, 1989), Hisatsugu Sugimoto, Shigeharu Tanabe, Nobuyuki Hata $(1969,1976,1993)$, Toshio Matsuyama $(1989,1993)$ once worked or are 
presently working. Among them Yuki Konagaya and Kazunobu Ikeya are the youngest.

Yuki Konagaya has studied Mongolian pastoral culture. After graduating from the Department of Geography of Kyoto University, she studied as an overseas student in Inner Mongolia. Her methodology depends upon both cultural anthropology and cultural geography. Konagaya (1991a, 1992a) has already published several attractive books for general readers, as well as many academic papers (Konagaya 1983, 1991b, 1992b).

Kazunobu Ikeya is one of the most energetic field workers among contemporary Japanese geographers. Ikeya commenced his field research on hunting cultures in remote mountain villages in Japan. In 1987 he moved to Africa, and undertook fieldwork on the San, the hunters and gatherers of the central Karahari (Ikeya 1993a, 1994a). Recently, he also conducted research on some pastoral cultures: the Somali in East Africa; and the Fulbe in West Africa (Ikeya 1993b). His methodology is also affected by cultural anthropologists with ecological perspectives, partly because of Kawakita's influence. In his recent papers, however, he has paid much more attention to the socio-cultural changes among these peoples which has altered their economic environments (Ikeya 1994b).

Masanori Naito has studied in the Middle East since the early 1980s, mainly on Syria and Turkey. During and after studying at a university in Syria, he conducted field research in both rural and urban areas and published many papers in English as well as in Japanese (Naito $1985,1987,1988 a, 1988 b)$. His main interest is on the political factors affecting urban and local spatial structures. Naito (1995) recently conducted a series of research on Turkish migrants in Germany. He also has made critical comments on the shortcomings of conventional Japanese geography (Naito 1989).

Keichi Kumagai commenced his research in Papua New Guinea in 1979-80 during his stay at the University of Papua New Guinea. Kumagai $(1985,1987)$ has conducted much fieldwork on urban migrant settlements in Port Moresby. He also has studied remote villages in Papua New Guinea's highland fringe using par- ticipant observation method (Kumagai 1988). His prime interest has been on rural-urban relationship and socio-cultural changes of Papua New Guinea. He recently extended his interest to the relationship between Japanese regional geography and area studies on the Third World (Kumagai 1992, 1996).

Many younger geographers are entering Third World studies. Masataka Tawa (1992) has undertaken field research on fishing cultures in Malaysia and Papua New Guinea, and published an attractive monograph describing socio-cultural and ecological change in a local community in the southern coast of Papua New Guinea (Tawa 1995). Tetsuo Sato $(1987,1993$, 1996) has researched on rural development in Bangladesh, agro-forestry in Thailand, and reproductive behavior in the suburban Bangkok; Junji Nagata $(1994,1996)$ has conducted his field research in rural Malaysia; Masao Kobayashi (1991) has researched on Nepalese villages; Kazuhiro Ajiki with Toyohiko Miyagi undertook field research on mangrove forests and environmental problem in the Philippines (Ajiki and Miyagi 1992); Kazuo Tomozawa (1991) has studied industrial change in India; Gen Endo $(1991,1996)$ has researched on urban population growth in Chiang Mai and analysed local economy of Thailand in terms of provincial businessman; Gen Ueda (1991, 1992, 1994) has studied urban petty production in Kenya and medium-sized firms in Nigeria; Wei-Dong $\mathrm{Xu} \quad(1987,1989,1990,1992)$ energetically published papers on recent economic changes in China; and Seii Yoh (Chienwei Yeh) (1989, 1994) has studied urban development in Taipei during Ching dynasty and the Japanese colonial era. An increasing number of stimulating papers appeared in academic journals during the last few years (Mitomi 1993; Matsumura 1993, 1997; Sawa 1994; Tsukihara 1994; Kimoto 1995; Sato, R. 1995).

The research topics pursued by the younger geographers are very different from each other in both content and methodology. But their research skills and language abilities are most promising. Unfortunately, their position in Japanese geographical circles is still marginal. There has not been much interaction between these geographers researching on the Third 
World and other geographers studying mainly Japanese topics. Consequently, the findings and methods used in Third World studies have not been properly located in Japanese geography. Further, younger geographers have often participated in interdisciplinary research organized by other academic disciplines. While this has stimulated their research it has also led to the questions of the validity of the geographical approach (see Takahashi 1982b; Maida 1984; Noma 1989; Naito 1989; Kumagai 1992, 1996; Hori 1996).

\section{Conclusion: Future Perspectives on Geographers and Third World Studies}

The foregoing discussion highlights divergence between Japanese geographers studying on the Third World and geographical circles in Japan since the Second World War.

Until the early 1960s, only a few human geographers undertook research on the Third World. These geographers had no track record and could not expect much academic financial support from the Japanese Government and other research institutions. Therefore, they had to develop their own research styles. Their emphasis was on intensive fieldwork with participatory observation. They were exceptional as the majority of Japanese geographers did not look outside Japan. Furthermore, the postwar reform of university education system also prompted Japan's geographical societies to demonstrate the unity of geography as a subject as well as an academic discipline (see Nippon Chiri-Gakkai 1975). In these circumstances, the pioneering geographers in Third World studies often became critical of conventional geography's methodology as well as the innate conservatism of geographical circles. Consequently, most pioneering geographers were marginalized in Japanese geography or gained recognition outside Japanese geographical circles.

Between the mid-1960s and 1970s, two major departments of geography-Tokyo University of Education and Hiroshima University-commenced their research activities in the Third World. They were at the core of Japanese geographical circles. They were not only the two largest geography departments in Japan with many physical and human geographers working together but also were responsible for educating secondary school geographers. High school or junior high school teachers have contributed large numbers of members to the Association of Japanese Geographers. ${ }^{19}$ Therefore the graduates from both departments occupied considerable proportions of the total number of members in the Association of Japanese Geographers. The research of both Departments focused on man-environment relationship. While their research succeeded in acquiring much detailed data, the results were mostly distributed within geographical circles and contributed little to other disciplines engaged in Third World studies. Their research also did not reflect the methodology and the epistemology developed by Japan's pioneering geographers on the Third World.

Since the 1980s, a greater variety of research has been undertaken by geographers on the Third World often in collaboration with academics from other disciplines. A number of younger geographers commenced their work in the Third World. Most of them did not come from mainstream academic geography but commenced their studies under the influence of various research in area studies. Regrettably, their research on the Third World seems to be still marginalized in Japanese academic geography.

Ideally, multidisciplinary studies should be favourably placed to tackle current Third World issues, as they are beyond the scope of any single discipline. Increasing collaboration between geographers and members of other disciplines has forced Japanese geographers to confront the role which geographers should play in interdisciplinary research. What is the distinctive geographical viewpoint? Is there any particular methodology or framework which geographers could advance? Should geography be dissolved into broader area studies of the Third World? Or can the geographers engaged in Third World studies renovate conventional geography? These are hard questions to address. The author, however, is not pessimistic about the contributions geographers could make to future Third World 
studies. Intensive fieldwork incorporating sensitivity to local environments, which is properly situated within the appropriate regional, national and global contexts would be highly valued. Also geographers have the responsibility to provide vivid and dynamic regional geographies of changing Third World societies to stimulate sympathetic understanding of these societies. Much of worth remains to be done.

(Received May 24, 1996)

(Accepted Mar. 28, 1998)

\section{Notes}

1. In this paper, 'Japanese geographers' includes not only the geographers with Japanese nationality but also the academics who are working or have worked mainly within Japanese geographical circles.

2. The author himself once reviewed the Japanese geographers' contributions to Third World research during the 1980s (Kumagai 1992). Yamashita (1992) also reviewed the contribution of Japanese geographers to the study of Southeast Asia after the Second World War. This paper partly draws on these earlier articles.

3. The author was mainly interested in internal migration and urbanization process in Southeast Asian countries and the Pacific Islands, and has been undertaking his own field research in Papua New Guinea since 1979.

4. Excluding the articles of physical geography in this paper reflects the reviewer's own interest and ability. The number and importance of field research undertaken by physical geographers in the Third World, however, should not be dismissed.

5. In 1935, for example, all of the seven articles of human and physical geography studying outside Japan were research on Japanese colonies: four articles on Taiwan; two on Manchuria; and one on Karafuto.

6. This trend would be altered if we took it into account English articles carried in the New series of Geographical Review of Japan (Series B) which was established in 1984 .

7. This was partly due to the journal being founded by geographers from the western part of Japan, who were mainly graduates from the University of Kyoto. Prior to the Second World War, the 'Kyoto school' geographers have had a tradition of engaging in studies of historical and cultural geography. Whereas geographers graduating from the University of Tokyo have contributed primarily to physical geography and economic or social geography.

8. The Japan Association of Economic Geographers holds its annual meeting as a symposium. Recently it has published a special issue of the annual symposium. In 1991 the Symposium was held under the title of 'Issues of Area Studies: the Case of Asian countries'. Five articles, three papers on East Asia (Okada 1992; Xu 1992, Miyakawa, Y. 1992) and two on Southeast Asia (Hirato 1992; Yamashita 1992), were carried in the Special Issue.

9. While these papers mostly used quantitative data and methods, only little research with socio-historical aspects has been conducted by Japanese geographers concerning Korea. Isao Mizuno (1995) criticized this tendency regarding it as Japanese geographers' attitudes to avoid the colonial history.

10. In Japan no universities or departments provide scholarships for postgraduate students intending to conduct research overseas. Postgraduate students had also been excluded from being formal members of the research teams awarded under the Grants-in Aid of Japan's Ministry of Education, Science and Culture until very recently.

11. At the University of Kyoto, no graduate and postgraduate courses in cultural anthropology had been available until recently.

12. The first project was the climatological and geomorphological research in East Africa by the Department of Geography at Tokyo Metropolitan University started in 1964.

13. Hiraoka did not belong to Tsukuba University's Department of Geography but has worked at the Department of Geography of Millersville University in Pennsylvania. His contribution, however, was remarkable for adding social and human aspects to the research (Hiraoka 1971, 1980, 1985, 1986).

14. The research was concentrated on: 1) physical characteristics of the land; 2) hydrological and climatological conditions; 3) vegetation; 4) agriculture; and 5) endemic diseases (Ichikawa 1981). Besides geographers, other natural scientists specializing on plant ecology, parasitology and heart surgery took part in the research.

15. The research in 1984 consisted of five topics: 1 ) climate; 2) landforms; 3) vegetation; 4) agricultural management; and 5) land use. Only the last two topics were surveyed by human geographers (Yamamoto 1986).

16. The Institute of Developing Economies recently published a series of books reviewing area studies on developing countries by Japanese academics, to commemorate the first thirty years of the Institute's life. Regrettably, there is no mention of the research conducted by the 
University of Tsukuba and Hiroshima University's geography departments.

17. This does not mean that geographical perspectives on man-environment relationship was eclipsed in Third World studies. Rather, they are becoming more significant in the context of increasing serious environmental problems in the Third World. Although still being under physical geographers initiative, the results of the study Group on Tropical Humid Environment (Tamura, Shimada, Kadomura and Umitsu 1995) shows some possibilities for collaborative research of physical and human geographers on this topic. Among a collection of papers in the volume, Shimada claimed that 'political ecology' approach should become a new and crucial framework considering the contemporary man-environment relationships in the Third World.

18. Since the mid-1980s, 'Chiri' (Geography), a popular journal especially for teachers of secondary schools, has published many special issues on the Third World topics as well as regional geographies of particular countries such as Taiwan, Peru or Papua New Guinea.

19. In 1993 the Association of Japanese Geographers had 2,892 members. Of those 25.4 per cent were geographers teaching at high schools. Geographers working at the universities (including part-time lecturers) occupied 34.6 per cent and further 7.5 per cent were post- and undergraduate students (Harayama 1996).

\section{References}

Abe, K. 1988. Urban system of modern Korea from the standpoints of economic management function. Annals of the Japan Association of Economic Geographers 34: 145-158. (JE)

Ajia Chiri Kenkyukai 1990. Henbo suru Ajia: NIEs, ASEAN no kaihatsu to chiiki henyo (Asia in transition: development and regional transformation in NIEs and ASEAN). Tokyo: Kokon Shoin. (J)

Ajiki, K. and Miyagi, T. 1992. On clearance of mangrove forest and expansion of fishpond in the Philippines. The Human Geography 44: 620-633. (JE)

Bekki, A. 1951. Population density of islands in monsoon region of eastern Asia. The Human Geography 3(2): 10-21. (J)

Bekki, A. 1957. Geographical consideration of navigation history on the Bay of Bengal. Geographical Review of Japan 30: 451-467. (J)

Bekki, A. 1959: A study of the navigation-routes near the coast of Sumatra in the early 17 th century: recorded in "Tong-si-yang-Kao". Geographical Review of Japan 32: 57-69. (JE)

Bekki, A. 1960a. Geographical studies on tropical area in South-eastern Asia. The Human Geography 12: 262-272. (J)

Bekki, A. 1960 b. Tonan Ajia shoto no kyoju to kaihatsushi ( $A$ history of settlement and development in Island Southeast Asia). Tokyo: Kokon Shoin. (J)

Bekki, A. 1969. Monsun Ajia: sono shizen to ningen (Monsoon Asia: the nature and the people). Tokyo: Institute of Development Economies. (J)

Bekki, A. 1977. Tonan Ajia chiiki kenkyu-shi josetsu: Raffuruzu no gyoseki o chusin ni (An introduction to the history of area studies on Southeast Asia: with special reference to Raffles' work). Tokyo: Kokon Shoin. (J)

Chai, Y. 1991. Urban internal structure of China's cities: a case study of Lanzhou city. The Human Geography 43: 526-545. (JE)

Chiba, T. 1951. Village types of Horonbeil. Geographical Review of Japan 24: 96-100. (JE)

Endo, G. 1991. A study on socio-economic cases of the recent population growth in Chiang Mai, northern Thailand. Annals of the Japan Association of Economic Geographers 37: 201-224. (JE)

Endo, G. 1996. Current trends and issues in studies of local economy in Thailand: with special reference to studies on provincial businessmen. The Human Geography 48: 449-467. (JE)

Fujii, H. 1971. Socialized farm in north Africa: the survey of the self-managed farm in Algeria and the cooperative farm in Tunisia. The Human Geography 23: 270-288. (JE)

Fujimaki, M. 1984. Reconsidering on city size distribution's studies of underdeveloped countries. Tenri Daigaku Gakuho (Tenri University Journal for Linguistics, Literature and Humanities) 141: 184-213. (J)

Fujimaki, M. 1989. An Indian squatter settlement in Kuala Lumpur: a preliminary report. Tenri Daigaku Gakuho 160: 205-248. (JE)

Fujimaki, M. 1993. Rethinking a concept of 'urban villagers': viewing from a study on Southeast Asian cities. In Toshijin no hakken ( $A$ discovery of urbanite), ed. S. Moriguri, 27-71. Tokyo: Mokujisha. $(\mathrm{J})$

Fujiwara, K. ed. 1980. Geographical field research in south India, 1978, a progress monograph. Hiroshima: Department of Geography, University of Hiroshima.

Fujiwara, K. ed. 1982. Geographical field research in south India, 1980. Hiroshima: The Research and Sources Unit for Regional Geography, University of Hiroshima.

Fujiwara, K. ed. 1984. Geographical field research in south India, 1982. Hiroshima: Department of Geography, University of Hiroshima.

Fujiwara, K. and Nakayama, S. 1985. Rural development in the drought prone areas of south Deccan plateau in India. Geographical Review of Japan 58B: $130-148$.

Fujiwara, K., Murakami, M., Nakayama, and Maida, I. 
eds. 1987. Kaigai chiiki-kenkyu no riron to giho (Theory and techniques for area studies overseas: $a$ geographical research on Indian villages). Hiroshima: Research Center for Regional Geography, Hiroshima University. $(\mathrm{J})$

Fujiwara, K. and Sadakata, N. 1988. Rural development and changes in land use in the semi-arid region of south India. Geographical Review of Japan 61 A: 143-154. (JE)

Fujiwara, K. and Sharma, R.C. 1992. Dynamic changes of Indian villages under rural development programmes. Annual Report of Research Center for Regional Geography (Hiroshima Univ.) 2: $1-30 .(\mathrm{JE})$

Goto, A. 1988. Technical adaptation of traditional agricultural methods in West Asia. Geographical Review of Japan 61A: 113-123. (JE)

Hagiwara, H. 1990. A comparative study of metropolitan water supply and drainage systems in developed and developing countries: the cases of Tokyo, Mexico City, Paris and Sao Paulo. Geographical Review of Japan 63B: 86-103.

Han, Ju-Seong 1982. Regional structure of passenger flows in Korea. The Human Geography 34: 481502. (JE)

Han, Ju-Seong 1988. The spatial organization of marketing networks by electric-domestic manufactures in Korea. Annals of the Japan Association of Economic Geographers 34: 145-158. (JE)

Han, Ju-Seong 1993. Development of a freight transportation network of regular trucking in Korea. The Human Geography 45: 309-323. (JE)

Harayama, M. 1996. Research topics and research areas of the Association of Japanese Geographers members, 1993. Geographical Review of Japan 69A: 263-276. (J)

Hashimoto, S. 1979. A study of the spatial aspects of the acculturation in the Torres Strait Islands. The Human Geography 31: 289-306. (JE)

Hashimoto, S. 1990. Irrigated cultivation of taro in the Shigatoka Valley, Fiji. Kansai Daigaku Bungaku Ronshu (Essays and Studies by Members of the Faculty of Letters) 39(2): 1-19.

Hashimoto, S. 1992. Meranesia: dento to kindai no soukoku (Melanesia: a conflict between tradition and modernity). Tokyo: Taimeido. (J)

Hata, N. 1969. Two types of swidden agriculture in tropics: on the cases of Nigeria, West Africa. The Human Geography 21: 341-369. (JE)

Hata, N. 1976. The native concept of seasonal cycle (months) and agricultural calendar of the Dourou society in North Cameroon. Bulletin of the National Museum of Ethnology 1: 537-564. (JE)

Hata, N. 1993. The economic lives of peasantry in Cameroon-Highland. Bulletin of the National Museum of Ethnology 18: 15-45. (JE)

Hayashi, H. 1959. Thoughts on Javanese place names. The Human Geography 11: 97-116. (J)

Hiraoka, M. 1971. Colonization and economic devel- opment in the Bolivian lowlands. The Human Geography 23: 554-570. (J)

Hiraoka, M. 1980. Japanese agricultural settlement in the Bolivian upper Amazon: a study in regional ecology. Latin American Studies 1: 1-160.

Hiraoka, M. 1985. Floodplain farming in the Peruvian Amazon. Geographical Review of Japan 58B: 1-23.

Hiraoka, M. 1986. Agricultural changes in Northeast Brazil: The Sitios of the Agreste in Paraiba. Latin American Studies 8: 63-89.

Hiraoka, M. and Yamamoto, S. 1981. Changing agricultural land use in the Agreste of Northeast Brazil. Latin American Studies 2: 81-124.

Hirato, M. 1976. Maraya no chiiki kozo: keisei to henyo (Regional structure of Malaya: its formation and transformation). Tokyo: Takushoku University. $(\mathrm{J})$

Hirato, M. 1988. A change in population distribution under the New Economic Policy in Malaysia. In Gendai Maresia no shakai keizai hendo: Bumiputora seisaku no 18 nen (The social and economic change in contemporary Malaysia: 18 years of Bumiputra Policy), ed. K. Horii, and N. Hagiwara, Tokyo: The Institute of Developing Economies. 235-284. (J)

Hirato, M. 1992. Industrialization and local capital in Malaysia. Annals of Japan Association of Economic Geographers 38: 11-18. (JE)

Hisatake, T.ed. 1991. Nippon ni okeru bunka chiri-gaku no tenkai (A development of cultural geography in Japan). Kobe: A report for the result of the research funded by the Fukutake Foundation. (J)

Hori, N. 1996. Geographical way of thinking on place and rejuvenation of regional geography. Annual Report of Research Center for Regional Geography 5: 9-19. (J)

Ichikawa, M. 1981. Summary of activities of the scientific survey on the natural environment, ecological systems, agricultural land use, and endemic diseases in the semi-arid regions of Latin America. Latin American Studies 2: 1-13.

Iizuka, K. 1950. "Genres de Vie" in East Asia. Oriental Culture 1: 1-22. (J)

lizuka, K. 1972. Man-Mou kiko (A trip to Manchuria and Mongolia). Tokyo: Chikuma Shobo. (J)

Ikeya, K. 1993a. Goat raising among the San in the central Kalahari. African Study Monographs 14 (1): 39-52.

Ikeya, K. 1993b. Pastoral economy of the Fulbe nomads in Nigeria. Geographical Review of Japan 66A: 365-382. (JE)

Ikeya, K. 1994a. Hunting with dogs among the San in the central Kalahari. African Study Monographs 15(3): 119-134.

Ikeya, K. 1994b. The development of remote rural area in Botswana: road construction and crafts production in Xade village. Monthly Journal of Institute of Developing Economies 35(11): 54-69. (J)

Ikuta, M. 1993. On the emerging international system 
of large cities in Southeast Asia. Kikan Keizai Kenkyu (The Quarterly Journal of Economic Studies) (Institute for Economic Research, Osaka City University) 16(2): 22-39. (J)

Ikuta, M. 1994. Japanese direct investment and urban economic growth in Malaysia, paper presented at Third International Conference "Geography of ASEAN Region”, Kuala Lumpur: 1-22.

Ikuta, M. 1995. The growth triangle in Singapore as a city state. The Toshi-Mondai Kenkyu (Journal of Municipal Problems) 47(1): 101-113. (J)

Ishida, H. ed. 1974. Geographical field research in Northwestern India: A Progress Monograph. Hiroshima: Department of Geography, University of Hiroshima.

Ishida, H. ed. 1975. Indo Panjabu no dotai-chishiteki kenkyu (Dynamic regional geographical studies of the Punjab, India), Hiroshima: Research Center for Regional Geography, Hiroshima University. (J)

Ishida, R. 1966. Geographical problems of Southeast Asia: with reference to the field of current research in geography. Journal of Geography 75(2): 61-69. (JE)

Ishihara, H. 1969. Periodical markets in Midnapore district, West Bengal. The Human Geography 21: 406-429. (J)

Ishihara, H. 1973. Periodical Markets of Ming, Ching and Min-Kuo Periods in Hopei province, China. Geographical Review of Japan 46: 245-263. (JE)

Ishihara, H. 1980. Markets in east-central China during Ming, Ching and Min-Kuo periods. The Human Geography 32: 193-213. (JE)

Ishihara, H. ed. 1987. Markets and marketing in rural Bangladesh. Nagoya: Dept. of Geography, Faculty of Letters, Nagoya University.

Ishihara, H. ed. 1988. Markets and marketing in South India. Nagoya: Dept. of Geography, Faculty of Letters, Nagoya University.

Ishihara, H. ed. 1989. Markets and marketing in West Bengal and East Nepal. Nagoya: Dept. of Geography, Faculty of Letters, Nagoya University.

Ishihara, H. ed. 1991. Markets and marketing in North India. Nagoya: Dept. of Geography, Faculty of Letters, Nagoya University.

Ishikawa, E. 1992. Nippon-jin no Oseania hakken (Discovery of Oceania by the Japanese). Tokyo: Heibonsha. $(\mathrm{J})$

Ishizuka, M. 1985. The social space in the Caribbean (I): the classification of space among people of the Lesser Antilles. In Kan-Karibu-kai chiiki ni okeru fukugo bunka no hikaku kenkyu (A comparative studies on the plural cultures in the circum-Caribbean Sea region), ed. M. Yamaguchi, M. and M. Naito, 85-109. Tokyo: the Institute for Studies of Languages and Cultures of Asia and Africa, Tokyo University of Foreign Studies: 85-109. (JE)

Ishizuka, M. 1987. Une analyse du paysage de plantation des Petites Antilles. In Social and festive space in the Caribbean: comparative studies on the plural societies, ed. M. Yamaguchi, M. and M. Naito, 115-171. Tokyo: the Institute for Studies of Languages and Cultures of Asia and Africa, Tokyo University of Foreign Studies. (F)

Ishizuka, M. ed. 1991. Karibu-kai sekai ( $A$ world of the Caribbean). Kyoto: Sekai Shiso-sha. (J)

Iwata, K. 1958. Agricultural Rituals in Laos. The Human Geography 10: 421-426. (J)

Iwata, K. 1963. The rice cultivation techniques in north Thailand. The Southeast Asian Studies 2: $22-38$. (J)

Iwata, K. 1964. The process of disorganization and reorganization of rural society in northern Thailand. The Southeast Asian Studies 11: 2-29. (J)

Iwata, K. 1967. A meaning of the Southeast-Asian studies: with major emphasis to minority problems. The Human Geography 19: 634-655. (J)

Iwata, K. 1971a. Tonan ajia no shosu minzoku (Ethnic Minorities in Southeast Asia). Tokyo: Nippon hoso shuppan kyokai. (J)

Iwata, K. 1971 b. Culture and place. Riso 452: 24-33. (J)

Iwata, K. 1973. So-moku-chu-gyo no jinrui-gaku: animizumu no sekai (Anthropology of the World of Animism). Sekai Shiso-sha (reprinted in 1991 by Kodan-sha) (J)

Iwata, K., Kobori, I., Takahashi, A., Yoshikawa, T., Sueo, Y. 1960. Overseas research and Geography (Round Table Talk). Chiri 5(12): 11-26. (J)

Jeon, Kyung-Sook 1982. The study on the changing processes of the activity space and the periodic market in Chung Cheong Buk province, Korea. Geographical Review of Japan 55A: 292-312. (JE)

Jeon, Kyung-Sook 1983. A study on the changing process of the central place system in Chung Cheong Buk province, Korea. Geographical Review of Japan 56A: 471-495. (JE)

Joo, Kyun-Sik 1982. Urbanization and urban system of Korea. Geographical Review of Japan 55A: 1-20. (JE)

Kamozawa, I. 1958. Some problems of the developments of the underdeveloped countries in the capitalistic world: Turkey and Central America. Annals of the Japan Association of Economic Geographers 5: 9-26. (JE)

Kamozawa, I. 1967. Some methodological problems of regional geography of society: standing on examples in the geography of Turkey. The Hitotsubashi Review 58: 15-32. (J)

Kamozawa, I. 1969. Toruko to Nippon no aida (Between Turkey and Japan). Tokyo: Hosei Univ. press. (J)

Kamozawa, I. 1988. Regional development policy in Turkey. In Gendai Sekai no Chiiki Seisaku (Regional Policies in A Contemporary World), ed. T. Kawashima, and I. Kamozawa, Tokyo: Taimeido. (J)

Kanasaka, K. 1985a. The conditions of drinking water supply and its project in rural Turkey. The 
Human Geography 37: 422-437. (J)

Kanasaka, K. 1985b. The drinking water supply at villages in Konya province, interior Anatolia. Annals of the Japan Association of Economic Geographers 31: 226-241. (J)

Katakura, M. 1987. Muslims in a non-Islamic environment: with a focus on Arab Muslims in Canada. Bulletin of the National Museum of Ethnology 12: 681-726. (JE)

Katakura, M. 1989. Muslims in a non-Islamic environment: a case study of Egyptian community in Vancouver, Canada. Bulletin of the National Museum of Ethnology 14: 821-889. (JE)

Kawabe, H. ed. 1988. Hattentojo-koku no toshi-sisutem (Urban system in developing countries). Tokyo: Institute of Developing Economies. (J)

Kawakita, J. 1957. Ethno-geographical observations on the Nepal-Himalaya. In Peoples of Nepal Himalaya: scientific results of the Japanese expeditions to Nepal Himalayas 1952-1953. Vol. 3 ed. H. Kihara, 1-362. Kyoto: Fauna and Flora Research Society, Kyoto Univ.

Kawakita, J. 1973. Yagai kagaku no hoho: shiko to tanken (A method of field science: thinking and exploration). Tokyo: Chuo Koron-sha. (J)

Kawakita, J. 1974. The hill Magars and their neighbours: hill peoples surrounding the Ganges Plain. Tokyo: Tokai Univ. Press.

Kawakita, J. 1977. The vertical structure of the central Nepal-Himalayan cultures: a prospect integrating three points of view: ecology; cultural history and development stage. Kikan Jinruigaku 8(1): 3-80. (J)

Kawakita, J. 1987. Soboku to bunmei (Naivety and civilization). Tokyo: Kodan-sha. $(\mathrm{J})$

Kikuchi, K. 1962. Process of modernizing land use in the Monsoon Asia: in the case of Thanh Hoa delta. Geographical Review of Japan 35: 413-426. (JE)

Kikuchi, K. 1966. Betonamu no nomin (Peasants in Vietnam). Tokyo: Kokon Shoin. (J)

Kikuchi, K. 1984. Tonan Ajia no kokka to jumin (States and the peoples in Southeast Asia). Tokyo: Kokon Shoin. (J)

Kikuchi, K. 1988. Betonamu no shosu minzoku (Ethnic minorities in Vietnam). Tokyo: Kokon Shoin. (J)

Kim, Doo-Chul 1995. Current trends and issues in studies of rural depopulation areas of Korea. The Human Geography 47: 21-45. (JE)

Kim Song-Mee 1991. On the relationships between choice of shopping place of consumers and their personal characterisitcs: a case study of Kwangju City, Korea. The Human Geography 43: 166-180. (JE)

Kimoto, K. 1995. The formation of a "royal city" in colonial India: a case study of Mysore. The Human Geography 47: 359-378. (JE)

Kitagawa, K. 1987. Urban problems in the Metropolitan cities in India: with a reference to Calcutta. In Shuraku chirigaku no tenkai (A development of settlement geography), ed. J. Yonekura, 161-180. Tokyo: Taimeido. (J)

Kobayashi, Masao 1991. The Changes in the bases of life at rural villages in Nepal hill. Regional Views, (Institute for Applied Geography, Komazawa Univ.) 4: 87-106. (J)

Kobayashi, Munehiro 1980. Structure of territorial organizations in the basin of Mexico during the Aztec period. The Human Geography 47: 97-121. (JE)

Kobayashi, Munehiro 1984. The structure of Guaman Poma's Mapamundi. The Human Geography 36: 193-214. (JE)

Kobayashi, S. 1991. Professor Jiro Kawakita and his "warmth index". In Nippon ni okeru bunka chirigaku no tenkai (A development of cultural geography in Japan), ed. T. Hisatake, 131-141. Kobe: A final report for the research funded by the Fukutake Foundation. (J)

Kobori, I. 1959. Human geography of subterranean irrigation systems in Western Asia: with special reference to the Qanat System. Memoirs of the Institute for Oriental Culture 19: 127-222. (JE)

Koga, M. 1958. Some problems on the regional development of the economy in India. Annals of Japan Association of Economic Geographers 5: 27-44. (J)

Koga, M. 1964. The peasant movement and land reform in India. Oriental Culture 34: 35-78. (J)

Koga, M. 1970. New facade of Indian agriculture: on the "green revolution". Monthly Journal of the Institute of Developing Economies 11(6): 76-94; 11 (7): $72-84 .(\mathrm{J})$

Koga, M. 1980. Rural-urban migration three cities of Northern India. Kikan Keizai Kenkyu (The Quarterly Journal of Economics), Institute for Economic Research, Osaka City University 3(1): 79-98; 3(3): 53-93. (J)

Koga, M. 1981. For the debate on the mode of production in Indian Agriculture. Kikan Keizai Kenkyu (The Quarterly Journal of Economic Studies) Institute of Economic Research, Osaka City University $4(3)$ : $1-36 ; 4(4): 33-59$. (J)

Koga, M. ed. 1985. Some aspects of urbanization in developing countries (A final report for Scientific Grants of Japan's Ministry of Education, Science and Culture). Tokyo: Hitotsubashi Univ.

Koga, M. ed. 1987. Daisan-sekai o meguru segurigeshon no shomondai (The questions of urban segregation concerning the Third World) (A final report for Scientific Grants of Japan's Ministry of Education, Science and Culture). Tokyo: Hitotsubashi Univ. (J)

Koga, M. 1988. A Development of regional policy in India. In Gendai sekai no chiiki seisaku (Regional policies in a contemporary world), ed. T. Kawashima, and I. Kamozawa, Tokyo: Taimeido. (J)

Kojima, Y. 1993. Some aspects on the life space derived from the research. Kobe Gaidai Ronso (The Kobe City University Journal) 30: 1-50. (J) 
Komai, S. 1993. Developing export-oriented economy in the northeast economic region of China. Annals of the Japan Association of Economic Geographers 39: 18-33. (JE)

Komoguchi, Y. 1972. Land use pattern and its development in east Bengal. Monthly Journal of Institute of Developing Economies 13(3): 28-45. (J)

Komoguchi, Y. 1986. Agricultural systems in Tamil Nadu: a case study of Peruvalanallur Village, Chicago: The Univ. of Chicago, Dept. of Geography, Research paper No. 219.

Komoguchi, Y. 1988-90. Rural community and agriculture in Bangladesh, part two; part three; part four. Regional Views (Institute for Applied Geography, Komazawa Univ.) 1: 81-103; 2: 113-132; 3: 149-170.

Komoguchi, Y. ed. 1995. Human ecology in rural Malaysia. Tokyo: Institute of Applied Geography, Komazawa University.

Komoguchi, Y. 1996. Migration and changing occupational patterns of FELDA's settlers in Malaysia: a case of Felda Ayer Hitam, Johor State. Regional Views (Institute for Applied Geography, Komazawa Univ.) 9: 63-86.

Konagaya (Toshimitsu) Y. 1983. Nomadic Pastoralism in Mongolia. The Human Geography 35: 548559. (JE)

Konagaya, Y. 1991a. Mongoru no haru: jinruigaku sukechi buk (Spring in Mongolia: an anthropological sketch book). Tokyo: Kawade Shobo Shinsha. (J)

Konagaya, Y. 1991b. Milking ritual of mares, cows and ewes in Mongolia. Bulletin of the National Museum of Ethnology 16: 589-632. (JE)

Konagaya, Y. 1992a. Mongoru mangekyo: sogen no seikatsu bunka (Mongolian kaleidoscope: life and culture in grasslands). Tokyo: Kadokawa Shoten. (J)

Konagaya, Y. 1992b. Castration of domestic animals and its ritual in Mongolia. Bulletin of the Institute for the Study of North Eurasian Cultures (Hokkaido University) 21: 121-161. (JE)

Kono, M. 1965. Recent trends of geographical studies in China after the republication of Dili Zhisi. The Human Geography 17: 285-301. (J)

Kono, M. 1978. Recent trends of geographical studies in China after the republication of Dili Zhishi. The Human Geography 30: 328-346. (J)

Kono, M. 1989. The rebirth of human geography in China. The Human Geography 41: 45-70. (J)

Kumagai, K. 1985. Spontaneous settlements in Port Moresby. Annals of the Japan Association of Economic Geographers 31: 1-23. (JE)

Kumagai, K. 1987. Rural-urban migration and ethnic group formation in a Papua New Guinea town: the case of Chimbu migrants in Port Moresby. Man and Culture in Oceania 3, Special Issue: 221238.

Kumagai, K. 1988. Taim balus i kam: a history of
Western contact and social change among the Mianmin people, Papua New Guinea. Bulletin of Hannan University (Humanities and Natural Science) 23(4): 1-20. (J)

Kumagai, K. 1992. Japanese geographers' studies on the Third World during the 1980s. In Keizai chiri-gaku no seika to kadai (Results and tasks of economic geography in Japan), Vol. 4. ed. Association of Economic Geographers, 241-271. Tokyo: Taimeido. (J)

Kumagai, K. 1996. Regional geography and area studies on the Third World. Annual Report of Research Center for Regional Geography 5: 35-45. (J)

Kumagai, K. and Shiota, M. eds. 1994. MatangiPashifika: taiheiyo tosho-koku no seiji shakai hendo (Matangi Pacifica: political and social transformation in the Pacific Island nations). Tokyo: the Institute of Developing Economies. (J)

Kurihara, H. 1974. The formation of the urban fringe of Mexico City: a case study. The Human Geography 26: 597-620. (JE)

Kurihara, H. 1978. The studies of urbanization in Latin America and the 'marginality' concept. Annals of the Japan Association of Economic Geographers 21: 1-18. (JE)

Lee, Hee-Sook 1997. The migration and re-settlement process of a clan group in Korea: a case study of the Chonju Ryu villages. The Human Geography 49: 201-221. (JE)

Maida, I. 1984. Overseas area studies and the thought of field work. The Human Geography 36(2): 131151. (J)

Maida, I., Minamino, T., Fujiwara, K., Kono, K. and Dalvi, A. S. 1992. Babhulgaon: Maratha's village developing by irrigation rush and sugarcane cultivation. Annual Report of Research Center for Regional Geography 2: 97-131. (JE)

Matsumoto, H. 1980. Some aspects of regional societies in Southwestern Papua. Ehime Daigaku Kyoyobu Kiyo (Bulletin of the Faculty of Liberal Arts, Ehime University) 13: 133-183. (JE)

Matsumoto, H. 1991. An ethnography or ethno-verse of wind: an another nature of Torres Strait Islanders. Bulletin of the National Museum of Ethnology 15: 193-235. (J)

Matsumura, Y. 1993. The development of ethnic minority policy in Yunnan province, China. The Human Geography 45: 490-514. (JE)

Matsumura, Y. 1997. State-building and ethnic problems in the development of China's autonomy policy. Human Geography 49: 331-352. (JE)

Matsuyama, T. 1989. A case study of life history of two Aboriginal men in Arnhem land, North Australia. Bulletin of the National Museum of Ethnology 14: 783-820. (JE)

Matsuyama, T. 1993. A note on government policy and urban Aborigines' life histories in Adelaide, South Australia. Bulletin of the National Museum of Ethnology 18: 409-451. (JE) 
Minamino, T. and Fujiwara, K. 1992. Water management and regional response in Chambal Project, India. Annual Report of Research Center for Regional Geography (Hiroshima Univ.) 2: 69-95. (JE)

Minamino, T., Iwao, M., Fujiwara, K. and Dalvi, A. S. 1992. Emergence of self-innovative community and its impacts on diverse paths in rural development. Annual Report of Research Center for Regional Geography (Hiroshima Univ.) 2: 133-161. (JE)

Mitomi, M. 1982. Underdevelopment, peripheral capitalism and the Cocoa Industry in Ghana. The Human Geography 34: 69-82. (JE)

Mitomi, M. 1993. The transformation of cosmology and spatial cognition among the Yami people of Orchid Island, Taiwan. Geographical Review of Japan 66A: 439-459. (JE)

Miyai, T. 1970. On communal land ownership in Mexico. The Human Geography 22: 65-83. (J)

Miyai, T. 1975. The settlement pattern and land division: from an Ejido village of Mexican Central Plateau. The Human Geography 27: 448-460. (JE)

Miyai, T. 1980. The collective Ejido in Mexico. Annals of the Japan Association of Economic Geographers 26: 245-256. (JE)

Miyakawa, Y. 1992. Mutation of politico-economic structure and metamorphosis of industrial system in East Asia. Annals of the Japan Association of Economic Geographers 38: 51-66. (JE)

Miyakawa, Z. 1958. Beginning of ancient civilization in Meso-American tropical forest. Geographical Review of Japan 31A: 333-346. (JE)

Miyamachi, Y. 1989. The village handloom industry in Tamluk sub-division, West Bengal, India. Annals of the Japan Association of Economic Geographers 35: 1-23. (JE)

Mizoguchi, T. 1987. Peddling activities of aluminum ware sellers in Bangladesh. Geographical Review of Japan 60B: 83-102.

Mizuuchi, T. 1985. Formation and development of a Japanese colonial city: Dalian from 1899 to 1945. The Human Geography 37: 438-455. (JE)

Mizuno, I. 1987. A simulation model of the spatiotemporal arrangement of periodic market systems: the case of South Ch'ungch'eong province, Korea in 1925. The Human Geography 39: 1-18. (JE)

Mizuno, I. 1995. Quantitative geography and the Japanese geographers' studies on Korea. Proceedings of the General Meeting of the Association of the Japanese Geographers 47: 242-243. (J).

Mori, H. 1991. Prawn culture and juvenile prawn fishing in West Bengal, India. The Human Geography 43: 583-596. (JE)

Morikawa, H. and Sung, Jun-Yong 1982. Central places and periodic markets in the surrounding areas of Kongju in Chung-Cheong Nam Do, Korea. Geographical Review of Japan 55: 757-778. (JE)
Motooka, T. 1958. The environments and the farming of the Caspian Sea coast in Iran. The Human Geography 10: 237-250. (JE)

Motooka, T. and Sakai, T. 1963. A review of basic literatures for human geographical studies on Southeast Asia. The Human Geography 15: 512531. (J)

Murakami, M. 1968. Geographical analysis of the industrialization in Singapore. Geographical Review of Japan 41: 541-570. (JE)

Murakami, M. et al. 1993. Geographical reappraisal of human resources and its relation to socioeconomic development in India. Annual Report of Research Center for Regional Geography (Hiroshima Univ.) 3: 23-114.

Murakami, M. et al. 1995. Geographical reappraisal of human resources and its impact on regional development in India. Annual Report of Research Center for Regional Geography (Hiroshima Univ.) 4: 29-115.

Nagata, J. 1994. A case study of a local land-lord and his estate management in lowland Johor. Southeast Asian Studies 32(3): 357-384. (JE)

Nagata, J. 1996. Coconuts, smallholders, and the ethnic mosaic: some observations on land ownership and land use in Mukim Sungai Punggor, Johor, Malaysia. Regional Views (Institute for Applied Geography, Komazawa Univ.) 9: 43-62.

Naito, M. 1985. The oasis of Damascus 1958-1983: Transformation and crisis of oasis village after land reform. Annals of the Japan Association of Economic Geographers 31: 169-191. (JE)

Naito, M. 1987. Crisis of Kufrayn village in the oasis of Damascus: spatial configuration under the process of national integration. Geographical Review of Japan 60B: 134-163.

Naito, M. 1988a. From the walled inner city to the urban periphery: changing phases of residential separation in Damascus. Hitotsubashi Journal of Arts and Sciences 29(1): 55-69.

Naito, M. 1988b. Al-Khalidiya: development and social formation of a squatter settlement on the urban periphery of Aleppo. Studies in the Mediterranean World: Past and Present 11: 75-98.

Naito, M. 1989. Rethinking modern geography: a regional view of the Third World, part one. Regional Views (Tokyo Institute for Applied Geography, Komazawa Univ.) 2: 21-36. (J)

Naito, M. 1995. Toruko-jin no Yoroppa: kyosei to haijo no taminzoku kokka (The West of Turks). Tokyo: Akashi Shoten. (J)

Naito, Y. 1995. Population composition and tourism distinction in Singapore. The Human Geography 47: 501-511. (JE)

Nakano, K. and Syahbuddin. 1992. Dynamics of land use of an equatorial highland in West Sumatra. Geographical Review of Japan 65B, 90-103.

Nakasato, T. 1989. Bovine keeping in the villages of western Ghats. Annual Report of Research Center 
for Regional Geography (Hiroshima Univ.) 1: 25100. (JE)

Nakasato, T. 1994. Differentiated diversification of occupation in a multi-caste village: a survey report from Kheda district. In Economic Changes and Social Transformation in Modern and Contemporary South Asia, eds. T. Taniguchi, H. Yanagisawa, T. Shinoda and F. Oshikawa, 533-579. Tokyo: Hitotsubashi University.

Nakasato, T., Fujiwara, K., Minamino, T., Singh, B. V. and Bager, S.R. 1992. Development of agriculture and rural-urban interaction in former Zamindari village: Dikhatpura. Annual Report of Research Center for Regional Geography (Hiroshima Univ.) 2: 31-67. (JE)

Nakashima, K. 1981. The origin of agriculture and cattle breeding in Egypt. The Human Geography 33: 23-40. (JE)

Nakayama, S. 1972. A geographical study of the industrializing process in the north-western India: problems and prospects. The Human Geography 24: 423-448. (JE)

Nakayama, S. 1982. Kita Indo ni okeru kogyo-ka katei (The industrialization process in North India). Tokyo: Kokon Shoin. (J)

Nakayama, S. 1986. A review of urban studies in India with special reference to the works by Indian scholars. The Human Geography 38: 145168. (JE)

Nakayama, S. 1991. Professor Hiroshi Ishida: his profile and research style. In Nippon ni okeru bunka chiri-gaku no tenkai ( $A$ development of cultural geography in Japan), ed. T. Hisatake, 84-106. Kobe: A final report for the research funded by the Fukutake Foundation. (J)

Nakayama, S., Fujiwara, K., and Kitagawa, K. eds. 1979. Regional development policies in India: problems and prospects. Annals of the Japan Association of Economic Geographers 25: 1-16. (JE)

Nam, Young-Woo 1981a. Prediction of the structure of functional regions within Seoul City: as an attempt for prediction of the future. The Human Geography 33: 507-524. (JE)

Nam, Young-Woo 1981b. The spatial structure and the characteristics of nodal regions with Seoul: based on daily movement of persons. Geographical Review of Japan 54: 637-659. (JE)

Nippon Chiri-Gakkai (The Association of Japanese Geographers) ed. 1975. Nippon Chiri-Gakkai 50 nenshi (A History of 50 years in the Association of Japanese Geographers). Tokyo: Kokon Shoin. (J)

Nishikawa, D. 1965. The expansion of Japanese immigration in Paraguay since the Second World War. Annals of the Japan Association of Economic Geographers 10: 11-38. (JE)

Nishikawa, D. 1968. Regional development of suburban agriculture in Brazil: a case study of Bragança Paulista, São Paulo State. Annals of the Japan Association of Economic Geographers 14: 22-
54. (JE)

Nishikawa, D. 1974a. The two ways of modernization of agriculture in Latin America. Monthly Journal of Institute of Developing Economies 15(8): 84-93. (J)

Nishikawa, D. ed. 1974b. Raten Amerika no nogyo kozo (Agricultural structure in Latin America). Tokyo: Institute of Developing Economies. (J)

Nishikawa, D. ed. 1985. Raten Amerika (Latin America). Tokyo: Taimeido. (J)

Nishikawa, D. 1990. The formation of "Pequena Propriedade" at the frontier in São Paulo State: case of a rural colony "MURA" near Presidente Prudente city. Hosei Daigaku Kyoyobu Kiyo (Bulletin of the Faculty of Liberal Arts, Hosei University) 63: 31-74. (J)

Nishizawa, T. 1988. Schematic framework for the study of the Caatinga. Latin American Studies 10: $1-12$.

Noh, T. 1959. On the formation of alang-alang: the grassland in Southeastern Asia. Geographical Review of Japan 22: 10-20. (JE)

Noma, H. 1982. Food habits and dietary system in a paddy-growing village of northeast Thailand. Memoirs of Nara University 11: 57-91. (JE)

Noma, H. 1988. The context of the time allocation studies in peasant societies: a review of developing countries' case. The Human Geography 40: 144-163. (J)

Noma, H. 1989. Geography and Southeast Asia. In Chirigaku no mosaku (Explorations in geography), ed. Department of Geography at Nara University, 127-145. Kyoto: Chijin Shobo. (J)

Noma, H. 1990. Land reclamation and agriculture in the Bengal lowland in the British period: A historicogeographic sketch. Southeast Asian Studies 28: 321-353. (JE)

Noma, H. 1995a. A review studies on village society and rural development in Bangladesh. Southeast Asian Studies 33: 115-140. (JE)

Noma, H. 1995b. Sustainability and people's participation on "Joint Study on Rural Development Experiment" project in Bangladesh. Studies in Geography, Nara Women's University 5: 109-141. (JE)

Oda, T. 1960. On Iranian agriculture. The Human Geography 12: 97-111. (J)

Oda, T. 1984. Studies of the origin and construction of Qanat: a review. The Human Geography 36: 433455. (J)

Oda, T., Takahashi, T., Sasaki, K., Ohwaki, Y. and Yamazumi, H. 1963. Recent geographical literatures of Africa. The Human Geography 15: 68103. (J)

Ohiwakawa, K. 1964. A study on the origin of Kibbutz: introduction to the study on the Jewish colonisation in Palestine. Annals of the Japan Association of Economic Geographers 9: 18-38. (J)

Ohiwakawa, K. 1969. Kibbutz Deganya: A Jewish Settlement in Palestine. In Ajia no noson (Rural 
villages in Asia), ed. M.Ohno, 271-361. Tokyo: The Univ. of Tokyo Press. (J)

Ohiwakawa, K. 1983. Gendai Isuraeru no shakai-keizai kozo (Socio-economic structure of contemporary Israel). Tokyo: Tokyo Univ. Press. (J)

Ohji, T. 1964. On the evolution from dry farming to irrigation farming: through the field survey in the northern part of west Pakistan. The Human Geography 16: 40-63. (JE)

Ohji, T. 1977. Notes on the image of the Indian village community in the Nineteenth century: with particular reference to the formation and decline of the microscopic research view points. The Human Geography 29: 483-519. (JE)

Ohji, T. 1984. Land utilization in a south Decan village: contrast between tank-irrigated and rain-fed cultivation. Southeast Asian Studies 22: 171-196.

Ohji, T. 1986. Normative approach to the study of periodic markets in south India. The Human Geography 38: 289-315. (JE)

Ohji, T. 1987. The characteristics of Indian rice farming. In Ine no Ajia shi (The history of rice cultivation in Asia), T. Watabe ed.vol.2 131-166. Tokyo: Shogakukan. (J)

Ohji, T. 1993. Traditional rice cultivation methods and a survey of plows in Thailand: in connection with the development of plow culture. Southeast Asian Studies 31: 104-131. (J)

Ohji, T. 1995. Traditional rice cultivation methods and a survey of plows in Thailand: with special reference to the development of plow technology. Southeast Asian Studies 33: 427-462.

Ohno, M. 1965-67. On socio-economic structure of Iranian villages. Memoirs of the Institute for Oriental Culture 38: 31-141, 39: 209-313, 40: 181290, 44: 129-239. (JE)

Ohno, M. ed. 1969. Ajia no noson (Rural villages in Asia). Tokyo: The Univ. of Tokyo Press. (J)

Ohno, M. 1971. Perusya no noson: mura no jittai chosa (Rural villages in Persia: a field research on villages). Tokyo: The Univ. of Tokyo Press. (J)

Ohno, M. 1974. Firudowaku no shiso (A thought of fieldwork). Tokyo: The Univ. of Tokyo press. (J)

Ohno, M. 1977. Misunderstanding in fieldwork: on the concept 'from nomadic pastoralism to settled agriculture'. Shiso 632: 141-155. (J)

Ohshima, G. ed.1983. Tores kaikyo no hitobito: sono chirigaku-teki minzokugaku-teki kenkyu (The Torres Strait Islanders: its geographical and ethnological study). Tokyo: Kokon Shoin. (J)

Ohshima, G. 1986. Between Australia and New Guinea: ecological and cultural diversity in the Torres Strait with special reference to the use of marine resources. Geographical Review of Japan 59B: $69-82$.

Ohshima, G. 1988. Pearl culture and the islanders' society of the Torres Strait. Geojournal 16(2): 157-168.

Okada, M. 1992. A prospect of Southeast Asia and strategy for promotion of Kyushu's socioeconomy. Annals of the Japan Association of Economic Geographers 38: 1-10. (JE)

Okahashi, H., Fujiwara, K., Nakasato, T., Tomozawa, K., and Oja, M.S. 1992. Rural-urban interaction and process of underdevelopment based on forest economy in tribal village: Gadher, Madhya Pradesh, India. Annual Report of Research Center for Regional Geography (Hiroshima Univ.) 2: 191226. (JE)

Onodera, J. 1991. Industrial restructuring in rural China: a case study in Jiangning County, Nanjing. Annals of the Japan Association of Economic Geographers 37: 383-406. (JE)

Osaka City University, Keizai Kenkyujo 1989. Sekai no Dai-Toshi: vol. 6; Bankoku, Kuara Rumpuru, Singaporu, Jakaruta (World Metropolis 6: Bangkok, Kuala Lumpur, Singapore, Jakarta). Tokyo: Tokyo Univ. Press. (J)

Ota, I. 1976. Ethnic groups in the Jurong industrial estate of Singapore. Geographical Review of Japan 49: 765-779. (JE)

Ota, I. 1985a. Language environment for Chinesespeaking societies in Malaysia and Singapore. Geographical Review of Japan 58A: 318-339. (JE)

Ota, I. 1985b. Recent changes in the Chinese-speaking environment of Singapore. Geographical Review of Japan 58B: 115-129.

Ota, I. 1994. Kokugo o tsukawanai kuni: Singaporu no gengo kankyo ( $A$ nation without using her national language: a language environment in Singapore). Tokyo: Kokon Shoin. (J)

Ota, I. 1997. Chiiki no sugata ga mieru kenkyu o (Towards a study grasping geographical reality: critical essays of late professor Isamu Ota). Tokyo: Kokon Shoin. (J)

Ota, K. 1967. A study of rice crop in Vietnam. The Human Geography 19: 306-315. (J)

Ota, K. 1968. The characteristics of roads and waterways in Mekong delta. Geographical Review of Japan 41: 196-200. (J)

Park, Jong-Hyum 1995. International urban system in terms of air passenger flow: a case of Fukuoka in the East Asia urban system. Annals of the Association of the Japan Association of Economic Geographers 41: 135-144. (JE)

Saito, I., and Yagasaki, N. 1987. Zonal patterns of agricultural land use in the state of Paraiba, Northeast Brazil. Geographical Review of Japan 60B: 66-82.

Saito, I., and Yagasaki, N. 1990. The Salinas and salt industry in Rio Grande do Norte, Northeast Brazil. Latin American Studies 11: 39-50.

Saito, I., and Yagasaki, N. 1991. Agro-industries in the middle São Francisco Valley. Northeast Brazil. Annals of the Japan Association of the Economic Geographers 37: 225-244. (JE).

Saito, I., Yagasaki, N., Pazera, E., and Mullar, K. 1986. Agriculture and land tenure in Salgado de Sao 
Felix along the middle reaches of the Paraiba river in Northeast Brazil. Latin American Studies 8: 91-123. (JE)

Saito, S. 1961. On the minor race people in China. The Human Geography 13: 521-541. (JE)

Saito, S. 1964. Concerning the stock-farming in the north-western China. The Human Geography 16: 275-293. (JE)

Sakai, T. 1964. Post-war Expeditions in Himalayan Region. The Human Geography 16: 408-424. (J)

Sasaki, K. 1957. Primitive agriculture in native South America. The Human Geography 9: 159-181. (J)

Sasaki, K. 1970. Nettai no yakihata: sono bunka chirigaku-teki hikaku kenkyu (Shifting cultivation in the tropics: the cultural geographic comparative study). Tokyo: Kokon Shoin. (J)

Sato, R. 1995. Seasonal labor allocation and diversification strategy of swidden agricultural system: a report from the Majangir, southwest Ethiopia. The Human Geography 47: 541-561. (JE)

Sato, Tetsuo 1987. Wet-rice Cultivation in Lowland Bangladesh. Geographical Review of Japan 60B: 117-133.

Sato, Tetsuo 1993. The farming system of agroforestry in Northern Thailand. Regional Views (Institute of Applied Geography, Komazawa University) 6: 3-19.

Sato, Tetsuo 1996. Reproductive behavior of suburban residents in Bangkok. Regional Views (Institute of Applied Geography, Komazawa University) 9: 23-33.

Sato, Tokiko 1987. Medical diagnosis and physician ethnicity in the travel patterns of patients on Oahu, Hawaii. Geographical Review of Japan 60B: 103-115.

Sawa, S. 1994. Community participation in improvement of urban settlement: Kampung Improvement Program in Jakarta. Annals of the Japan Association of Economic Geographers 40: 165-183. (JE)

Segawa, S. 1995. The nation-state visualized: beautiful Indonesia in miniature park and the monopoly of design, location and reading. The Human Geography 47: 215-236. (JE)

Senda, M. 1975. The reconstruction of neolithic landscape in north China. The Human Geography 27: $1-82 .(\mathrm{J})$

Shibuya, S. 1991. Influence of Pung-su in Korean eup-settlement. The Human Geography 43: 5-25. (JE)

Shimada, S. 1981. Historical origin of regional problems in Nigeria. Monthly Journal of Institute of Developing Economies 22(5): 2-24, 22(6): 66-86. (J)

Shimada, S. 1989. A study of recent social change in rural Nigeria: finding from a field Survey on labour migration at Ebiya village, Kwara State. The Human Geography 41: 319-341. (JE)

Shimada, S. 1992. Chiiki-kan tairitsu no chiiki kozo: Naijeria no chiiki mondai (Regional structure of the conflicts between regions: regional problems in $\mathrm{Ni}$ geria). Tokyo: Taimeido. (J)

Shirasaka, S. 1988. The agricultural development of hill stations in tropical Asia: a Case study in the Cameron Highlands, Malaysia. Geographical Review of Japan 61B:

Sueo, Y. 1961. Introductory remarks to the agropastoral lives in the South-west Asia. The Human Geography 13: 264-276. (J)

Sueo, Y. ed. 1985. The utilization of water and water power in Turkey. Osaka: Kansai University Scientific Mission to Anatolia, Turkey.

Sueo, Y.ed. 1989. Toruko no mizu to shakai (Water and society in Turkey). Tokyo: Taimeido. (J)

Sugimoto, H. 1972. Nishi Samoa no nihonjin shucho (A Japanese chief in Western Samoa). Tokyo: Kokon Shoin. (J)

Sugimoto, H. 1978. Villages and dwelling houses of Hammond Island, Torres Strait. Bulletin of the National Museum of Ethnology 3: 95-113. (JE)

Sugimoto, H. 1982. Villages and dwelling houses in the Torres Strait region. Bulletin of the National Museum of Ethnology 7: 1-57. (JE)

Suizu, I. 1963. The rectangular land-allotments and the field system in ancient North China. Geographical Review of Japan 36: 1-23. (JE)

Tajima, H. 1965. Agriculture of the Chancay Valley in Peru. Annals of the Japan Association of Economic Geographers 10: 1-10. (JE)

Takagi, H. 1970. Plaza and its function in a Mexican highland community, Tepeojuma. Geographical Review of Japan 43: 22-31. (JE)

Takagi, H. 1971a. Rurban community of a Mexican highland Municipio: Tepeojuma. Geographical Review of Japan 44: 828-838. (JE)

Takagi, H. 1971b. Plaza and its function of the cities in Anahuac highland. The Human Geography 23: 435-449. (JE)

Takagi, H. 1977. Socio-economic change of Bastos, a Japanese colony in Brazil. The Human Geography 29: 96-112.(JE)

Takagi, T. 1982. The development of railway businesses and the regionalization in Argentine (1850-1914). Annals of the Japan Association of Economic Geographers 28: 181-198. (JE)

Takahashi, A. 1967. A note on socio-economic structure of Philippine villages. Oriental Culture 43: 49-76. (J)

Takahashi, A. 1969a. Land and peasants in Central Luzon: socio-economic structure of a Bulacan village. Tokyo: Institute of Developing Economies.

Takahashi, A. 1969b. Barrio Katulinan: A rice cultivating village in Philippines. In Ajia no noson (Rural villages in Asia), ed. M. Ohno, 37-115. Tokyo: The Univ. of Tokyo Press. (J)

Takahashi, A. 1977. Hired labour and agricultural changes in the rural Philippines. Monthly Journal of Institute of Developing Economies 18 (6/7): 4- 
$28(\mathrm{~J})$

Takahashi, A. 1982a. Land and labour in Barrio Bulacan: a socio-economic structure of rural village in Central Luzon. Keizaigaku Ronshu (The Journal of Economics) (Univ. of Tokyo) 47(4): 88113. (J)

Takahashi, A. 1982b. Economics and non-Western world: from the standpoint of Asian studies. In Daisan-sekai to keizaigaku (The Third World and economics), Takahashi et al. eds. 255-270. Tokyo: The Univ. of Tokyo press. (J)

Takahashi, N. 1985. Structure of financial space in Mexico. In Mekisiko-shi no Toshi Hatten (Urban Development of Mexico City), A. Hosono, ed. 79121. Tsukuba: Tsukuba Univ. (J)

Takahashi, N., and Yoshikae, N. M. 1983. Structure de L'espace financier au Bresil. Latin American Studies 7: 77-102. (S)

Takahashi, S. 1990. Remains of capital cities in Eastern Asia. The Human Geography 42: 442-465. (JC)

Takahashi, T. 1960. Consideration of the Mediaeval Islamic geography. The Human Geography 12: 361-374. (J)

Takaya, Y. 1980. The reclamation of the Chao Phraya Delta. Southeast Asian Studies 17: 633-657. (JE)

Takaya, Y., and Tomosugi, T. 1972. Three types of paddy-fields and their expansion in the Northeast of Thailand. Monthly Journal of Institute of Developing Economies 13 (9): 66-72. (J)

Takayama, R., and Kobayashi, S. 1991. A comprehensive bibliography of professor Jiro Kawakita. In Nippon ni okeru bunka chiri-gaku no tenkai ( $A$ development of cultural geography in Japan), ed. T. Hisatake, 142-162. Kobe: A final report for the research funded by the Fukutake Foundation. (J)

Takeuchi, K. 1974. Geopolitics and geography in Japan. The Hitotsubashi Review 72: 169-191. (J)

Takeuchi, K. 1976. Social geography and the Third World: some cases of urban studies. The Hitotsubashi Review 75: 143-161. (J)

Takeuchi, J. 1971. Irrigation development and land use on the Tao Yuan tableland in Taiwan. Geographical Review of Japan 44: 665-684. (JE)

Tamura, T., Shimada, S., Kadomura, H., and Umitsu, M. eds.(1995): Nettai shitsujun kankyo (Humid tropical environment). Tokyo: Asakura Shoten. $(\mathrm{J})$

Tanabe, S. 1972. On the Thai administrative area in the late Ayutthaya and the early Bangkok period. The Southeast Asian Studies 10: 246-283. (J)

Tanabe, S. 1976. The irrigation system in Nong Paman: a Lannathai village in Northern Thailand. Bulletin of the National Museum of Ethnology 1: 671-777. (JE)

Tanabe, S. 1994. Ecology and practical technology: peasant farming system in Thailand. Bangkok: White Lotus.

Taniuchi, T. 1982. Papua Nyu Ginia no shakai to keizai (The society and economy of Papua New Guinea). Tokyo: Institute of Developing Economies. (J)
Tawa, M. 1991. Professor George Ohshima: his personality and style of the research. In Nippon ni okeru bunka chiri-gaku no tenkai ( $A$ development of cultural geography in Japan), ed. T. Hisatake, 109119. Kobe: A final report for the research funded by the Fukutake Foundation. (J)

Tawa, M. 1992. Fishing ground use at the commercial fishing area in the Malay Peninsula: the case of Parit Jawa, Johore State. The Human Geography 44: 507-523. (J)

Tawa, M. 1995. Kawariyuku Papua Nyu Ginia (Changing Papua New Guinea). Tokyo: Maruzen. (J)

Terasaka, A. ed. 1989. Geographical views in the Middle Eastern Cities, I: Turkey. Ibaraki.

Terasaka, A. ed. 1992. Geographical views in the Middle Eastern Cities, III: Ankara. Ibaraki.

Terasaka, A. ed. 1994. Isuramu toshi no henyo: Ankara no toshi hattatsu to chiiki kozo (The transformation in a Islamic city urban development and regional structure in Ankara). Tokyo: Kokon Shoin. (J)

Tomosugi, T. 1969. Muban Sankaptong: a rice cultivating village in Northern Thailand. In Ajia no noson (Rural villages in Asia) ed. M. Ohno, 117191. Tokyo: The Univ. of Tokyo Press. (J)

Tomosugi, T. 1980. Structural analysis of Thai economic history. Tokyo: Institute of Developing Economies.

Tomosugi, T. 1983. On markets in Thailand. Oriental Culture 63: 95-139. (J)

Tomosugi, T. 1989. Landscape representative of urban past experiences in Bangkok: money, Buddhism and kingship. Oriental Culture 69: 1-46. (J)

Tomosugi, T. 1990. Suriranka, Goru no shozo: minamiAjia chiho toshi no shakai-shi (Portrait of Galle: a social history of regional city in South Asia). Tokyo: Dobunkan. (J)

Tomosugi, T. 1991. Rethinking the substantive economy in Southeast Asia: on the margins between utilities and meanings. Tokyo: The Institute of Oriental Culture, the Univ. of Tokyo.

Tomosugi, T. 1993. Reminiscences of old Bangkok: memory and the identification of a changing society. Tokyo: The Institute of Oriental Culture, the Univ. of Tokyo.

Tomosugi, T. 1995. Changing features of a rice-growing village in central Thailand: a fixed-point survey from 1967 to 1993. Tokyo: The Centre for East Asian Cultural Studies for UNESCO, The Toyo Bunko.

Tomozawa, K. 1991. Evolution of automobile industry in India: principally through the survey of Japan-India joint ventures. Annals of the Japan Association of Economic Geographers 37: 313-333. (JE)

Tomozawa, K., Okahashi, H., Fujiwara, K., Kono, K., and Nath, M.L. 1992. Socio-economic change of a Banjara village Naharkheda in Vindhya Range. Annual Report of Research Center for Regional Geography (Hiroshima Univ.) 2: 163-190. (JE) 
Tsuji, R. 1985. The distribution of Mook (processed acorn) in the market of Taegu city, Korea. The Human Geography 37: 374-384. (J)

Tsukihara, T. 1994. Livestock types and farming system: an agro-pastoral linkage in Ladakh, Northern India. The Human Geography 46: 1-21. (JE)

Ueda, G. 1991. Open-air and small-scale enterprise in urban Kenya: an attempt to classify urban centres with reference to employment statistics. Monthly Journal of Institute of Developing Economies 32(9): 44-63. (J)

Ueda, G. 1992. Social relations in urban petty production: market traders in Nyeri, Kenya. The Science Reports of the Tohoku University 7th Series (Geography) 42(2): 75-106.

Ueda, G. 1994. Dynamics of medium-sized firms: the changing industrial geography under structural adjustment in Tanzania mainland. The Science Reports of the Tohoku University, 7th Series (Geography) 44(2): 99-150.

Ueno, K. 1992. Development and regional inequalities of rural nonagricultural enterprises in China. The Human Geography 44: 242-261. (JC)

Umehara, H. 1970-71. The role of landlords in agricultural development of Philippines (I), (II). Monthly Journal of Institute of Developing Economies 11(4): 111-117, 12(2): 66-74. (J)

Umehara, H. 1978. 'Green revolution' and peasants in the Philippines. Monthly Journal of Institute of Developing Economies 19(9): 26-40. (J)

Umehara, H. 1987. Technological innovation and agrarian change in the Philippines: with special reference to rice farming in the 1970s. Geographical Review of Japan 60B: 20-40.

Umehara, H. ed. 1988. Tonan ajia nogyo no shogyo-ka (Commercialization of agriculture in Southeast Asia). Tokyo: Institute of Developing Economies. (J)

Umehara, H. ed. 1991. Tonan Ajia no tochi seido to nogyo henka (Land tenure and agricultural change in Southeast Asia). Tokyo: Institute of Developing Economies.

Umehara, H. 1992. Firipin no noson: sono kozo to hendo (Rural villages in the Philippines: their structure and transformation). Tokyo: Kokon Shoin. (J)

Umehara, H., and Mizuno, K. eds. 1993. Tonan Ajia noson kaiso no hendo (Agrarian differentiation in Southeast Asia). Tokyo: Institute of Developing Economies. $(\mathrm{J})$

Wada, S. 1953. Ancient Mayan civilization: with a special reference to the natural environment of tropical regions. The Human Geography 5: 341354. (J)

Xu Pei-Wei, and Saito, M. 1994. Satellite towns of Beijing city and their problems. The Human Geography 46: 642-657. (JE)

$\mathrm{Xu}$ Wei-Dong 1987. Recent aspects of regional development and foreign capital introduction in China.
Annals of the Japan Association of Economic Geographers 33: 200-216. (JE)

$\mathrm{Xu}$ Wei-Dong 1989. Recent aspects of industrial development and foreign capital introduction in Zhujiang delta, southern China. Annals of the Japan Association of Economic Geographers 35: 320-334. (JE)

$\mathrm{Xu}$ Wei-Dong 1990. Some aspects of agricultural regionalization in Hainan Island, south China. The Human Geography 42(3): 195-219. (JE)

$\mathrm{Xu}$ Wei-Dong 1992. Some aspects of the change of industrial location under economic reform policy in China. Annals of the Japan Association of Economic Geographers 38: 19-36. (JE)

Xu Wei-Dong, Shirasaka, S., and Ichikawa T. 1990. Farming system and settlements in Xishuangbanna, Yunnan Province, China. Geographical Review of Japan 63B: 104-115.

Yabuuchi, Y. 1963. Studies on the cultural interchange in the area of Pacific Islands. The Human Geography 15: 401-417. (J)

Yabuuchi, Y. 1967. Porinesia: kazoku, tochi, Jukyo (Polynesia: family, land and shelter). Tokyo: Taimeido. (J)

Yabuuchi, Y. 1969. Tonan Ajia no hyokai-min (Nomadic maritime people in Southeast Asia). Tokyo: Kokon Shoin. (J)

Yagasaki, N., and Saito, I. 1992. Development of the sugar industry and the structure of sugar cane supply areas in the Goiana valley, Northeast Brazil. The Geographical Review of Japan 65A: 1739. (JE)

Yamaguchi, Y. 1970. Tonan ajia no chishi (A regional geography of Southeast Asia). Tokyo: Bunka Shobo Hakubunsya. (J)

Yamakawa, M. 1982. Kinship and socio-economic structure of Barangay Mamandil in Central Luzon. Annals of the Japan Association of Economic Geographers 28: 199-215. (JE)

Yamamoto, S. 1986. Outline of the scientific expedition on the land use and change of ecosystems in northeast Brazil. Latin American Studies 8: 1-9.

Yamamoto, S., and Hiraoka, M. 1977. Three farm types in the Patos Basin of the inland Paraiba State, Brazilian Northeast. Geographical Review of Japan 50: 511-529. (JE)

Yamamoto, S., Nishizawa, T., Hayashi, I., Matsumoto, E., Saito, I. Yagasaki, N., Kashiwagi, Y. and Watanabe, T. 1986. Natural environment and land use around Petrolina-Juazeiro, central Part of Northeast Brazil. Latin American Studies 8: 125-147.

Yamashita, K. 1985. The segregation and its breakdown of Chinese dialect groups in Singapore. Geographical Review of Japan 58A: 295-317. (JE)

Yamashita, K. 1986. The residential segregation of Chinese dialect groups in Singapore: with focus on the period before ca. 1970. Geographical Review of Japan 59B: 83-102. 
Yamashita, K. 1987. Tonan Ajia no Chaina taun (Chinatowns in Southeast Asia). Tokyo: Kokon Shoin. (J)

Yamashita, K. 1988. Singaporu no kajin shakai (The Chinese society in Singapore). Tokyo: Taimeido. (J)

Yamashita, K. 1992. Contribution of Japanese geographers to the study of Southeast Asia after World War II. Annals of the Japan Association of Economic Geographers 38: 11-19. (JE)

Yamori, K. 1962. A study of the distribution and the scale of the walled towns in Ri Dynasty. Geographical Review of Japan 35: 1-13. (JE)

Yoh, S. 1989. Urban formation of Taipei City during Ching Dynasty. Ochanomizu University Studies in Arts and Culture 42: 1-21 (J)

Yoh, S. 1994. Urban planning of Taipei under Japanese rule. Annals of the Japan Association of Economic Geographers 40: 202-219. (JE)
Yoshida, K. 1952. Pa-Si-Pheong: traveling fishing village in Korea. The Human Geography 4: 379-391. (JE)

Youn, Jeong-Suk 1987. The study of residential segregation by ethnic groups in Incheon, Korea. The Human Geography 39: 279-293. (J)

Yokoyama, S. 1965. The development of plastic industry in Hong Kong and its international competitive power. The Human Geography 17: 609629. (JE)

Yokoyama, S. 1966. A study of the economic interdependence between Hong Kong and Mainland China from the view point of trade relations. Annals of the Japan Association of Economic Geographers 12: 56-70. (J)

Yonekura, J. ed. 1973. Indo shuraku no henbo (Recent changes on settlements in India). Tokyo: Kokon Shoin. (J) 